\title{
Örgüt İkliminin İşyeri Nezaketsizliği Üzerine Etkisinde Makyavelist Kişilik Özelliklerinin Düzenleyici Rolü
}

\begin{tabular}{l} 
Ferda ÜSTÜN ${ }^{1}$ \\
Şeyma ERSOLAK \\
Yayın Tarihi/ Published \\
$15 / 04 / 2020$ \\
\hline
\end{tabular}

\begin{tabular}{lcc}
\multicolumn{1}{c}{$\begin{array}{c}\text { Geliş Tarihi/ Received } \\
\text { 09/12/2019 }\end{array}$} & Kabul Tarihi/ Accepted & Yayın Tarihi/ Published \\
$18 / 03 / 2020$ & $15 / 04 / 2020$ \\
\hline Citation/Atıf: Üstün, F., Ersolak, S., (2020), Örgüt İkliminin İsyeri Nezaketsizliği Üzerine \\
$\begin{array}{l}\text { Etkisinde Makyavelist Kişilik Özelliklerinin Düzenleyici Rolü, Atatürk Üniversitesi İktisadi ve } \\
\text { İdari Bilimler Dergisi, 34(2): 433-460, DOI: 10.16951/atauniiibd.657279 }\end{array}$ \\
\hline
\end{tabular}

Öz: Bu araştırmanın amacı destekleyici ve 1lımlı örgüt iklimi algısının iş yeri nezaketsizliği üzerine etkisinde kişilik özelliklerinden makyavelizmin düzenleyici rolünün belirlenmesidir Kayseri ve Eskişehir il merkezinde faaliyet gösteren banka çalışanları üzerine gerçekleştirilen bu araştırmada bağımlı ve bağımsız değişkenler ile düzenleyici değişkenin birbiri ile ilişkileri, ortaya konulan araştırma modeli ile incelenmiştir. Araştırma sonucunda çalışanların destekleyici ve 11 ımlı örgüt iklimi algıları ile iş yeri nezaketsizliği ve makyavelizm arasında negatif yönlü anlamlı ilişki tespit edilmiştir. Yapılan hiyerarşik regresyon analizi sonucunda ise çalışanların destekleyici ve 1lımlı örgüt iklimi algıları ile iş yeri nezaketsizliği arasındaki ilişkide makyavelist kişilik özelliklerinin düzenleyici bir role sahip olduğu görülmüştür. Buna göre düşük makyavelist kişilik özelliğine sahip çalışanlar için destekleyici ve 1lımlı örgüt iklimi algısı yükseldikçe iş yeri nezaketsizliği azalırken; yüksek makyavelist kişilik özelliğine sahip çalışanlar için destekleyici ve ${ }_{11}$ ımlı örgüt iklimi algısı artıkça iş yeri nezaketsizliğide artmaktadır. $\mathrm{Bu}$ anlamda örgüt içinde yaratılacak destekleyici ve 1lımlı örgüt iklimi her zaman yıkıcı tutum ve davranışlar bütünü olan iş yeri nezaketsizliğini önlemeye yardımcı olmamaktadır. Araștırma sonuçlarına göre asıl belirleyici unsurun kişilerin sahip oldukları makyavelist kişilik özellikleri olduğu söylenebilir.

Anahtar Kelimeler: Destekleyici ve Ilımlı Örgüt İklimi, İş yeri Nezaketsizliği, Makyavelist Kişilik Özellikleri

The Moderating Role of the Makievelist Personality in the Effect of Organizational Climate on Workplace Disability

Abstract: The aim of this study is to determine the moderate role of machiavelism among personality traits in the effect of bank employees supportive and moderate organizational climate on workplace incivility. In this study on bank employees operating in Kayseri and Eskişehir provinces, the relationship between dependent and independent variables and moderating variable was examined through the research model put forward. As a result of the research, a negative relationship was found between the employees perceptions of supportive and moderate organizational climate and workplace incivility and machiavelism. As a result of the hierarchical regression analysis, it has been seen that machiavelist personality traits have a moderating role in

${ }^{1}$ Dr. Öğr. Üyesi, Nevşehir Hacı Bektaş Veli Üniversitesi İktisadi ve İdari Bilimler Fakültesi, İşletme Bölümü https://orcid.org/0000-0002-7397-8048

${ }^{2}$ Lisansüstü Öğr., Nevşehir Hacı Bektaş Veli Üniversitesi, Sosyal Bilimler Enstitüsü, https://orcid.org/0000-0002-5319-7260 
Örgüt İkliminin İşyeri Nezaketsizliği Üzerine Etkisinde Makyavelist Kişilik Özelliklerinin Düzenleyici Rolü

the relationship between employees perceptions of supportive and moderate organizational climate and workplace incivility. Accordingly, while the perception of supportive and moderate organizational climate increases for employees with low machiavelist personality, workplace incivility decreases. But while the presence of a supportive and moderate organizational climate increases for employees with a high machiavelist personality, workplace incivility increases. In this sense, the supportive and moderate organizational climate to be created within the organization does not always help prevent workplace incivility, which is a set of destructive attitudes and behaviors. According to the results of the research, it can be said that the main determining factor is the machiavelist personality traits of the individuals.

Key Words: Supportive and Moderate Organizational Climate, Workplace Incivility, Machiavellism.

\section{EXTENDED SUMMARY}

Purpose: The aim of this study is to determine the moderate role of machiavelism among personality traits in the effect of bank employees supportive and moderate organizational climate on workplace incivility.

\section{Research Hypotheses:}

$\mathrm{H}_{1}$ : The climate of the supportive organization has a negative and significant impact on workplace incivility.

$\mathrm{H}_{2}$ : Machiavellian personality plays a regulatory role between the climate of the supporting orgnazition and the incivility of the workplace.

Method: The data used in the study conducted on private and public bank employees working in Kayseri and Eskişehir city center between NovemberMarch 2018 were collected by survey method. In this sense, the support and moderation dimension of the Organizational Climate Scale, developed by Robert Stringer (2002) to measure supportive and moderate organizational climate, was measured by Cortina et al. (2001) and the Machiavellicism Scale, developed by Dahling, Whitaker and Levy (2009) to measure machiavelist personality traits.

In order to measure the construct validity of scales, explanatory (EFA) and confirmatory factor analysis (CFA) were used. This analysis was used separately for each scale. In this way, it was determined that the scale have goodness of fit values. Firstly, descriptive statistics were made and then hierarchical regression analysis was conducted to determine the role of machiavelist personality traits in the relationship between supportive and moderate organizational climate and workplace incivility.

Findings: Correlation analysis was performed to determine the relationship between the variables. According to the results of thes analysis, a significant and negative relationship was found between supportive and moderate organizational climate and workplace incivility $(\mathrm{r}=-0.40$ and $\mathrm{p}<0.01)$ and machiavelist personality trait $(\mathrm{r}=0.06$ and $\mathrm{p}<0.05)$. There was a positive relationship between machiavelism and workplace incivility $(r=0.22 ; \mathrm{p}<0.01)$. As a result of the hierarchical regression analysis, all stages of the model are statistically significant. In the first group, there is no interaction term, and it is seen that the supportive and moderate organizational climate $(\mathrm{F}(1,183)=34,809$; $\mathrm{p}=.000$ ) makes a significant contribution to the regression model. In the second 
group, supportive and moderate organizational climate and machiavellism ( $\mathrm{F}$ $(2,182)=22,740 ; \mathrm{p}=.000)$ were found to contribute significantly to the regression model. Corrected R2 values are 0.16 and 0.20 , respectively. This result shows that $\% 16$ of the change in workplace incivility explains the supportive and moderate organizational climate, and \%20 explains the supportive and moderate organizational climate together with machinavelis. When the coefficients of the models were examined, the supportive and moderate organizational climate $(\mathrm{B}=$ $-, 414, \mathrm{p}<0.01)$ included in the first group had a significant effect. In the second group, the supportive and moderate organizational climate $(B=-, 428, p<0.01)$ and machiavelism $(\mathrm{B}=, 179, \mathrm{p}<0.01)$ included in the model had a significant effect on workplace incivility. Finally, in the third group, the supportive and moderate organizational climate $(\mathrm{B}=-456, \mathrm{p}<0.01)$ and machiavelism $(\mathrm{B}=, 085$, $\mathrm{p}<0.01)$ and the interactive term $(\mathrm{B}=, 254, \mathrm{p}<0.01)$ were included in the model has a significant impact on incivility.

Discussion and Conclusion: As a result of the analyzes, it is seen that the supportive and moderate organizational climate has a negative and significant effect on workplace incivility. In this sense, it can be said that in the organizations where a moderate, supportive and positive organizational psychology is created workplace incivility will decrease. This result of the research shows parallelism with the literature. Taştan (2014) found moderate positive and significant relationship between organizational climate and workplace incivility. In this sense, the first hypotesis of the study, "H1: Supporting organizational climate, negatively and significant affects workplace incivility "was accepted. In the analysis conducted to test the second hypotesis of the study, machiavelist personality traits were included in the model as a regulator in the effect of the supportive and moderate organizational climate on workplace incivility. As a result of the analysis, machiavelist personality traits played regulatory role in the model. In the other words, it can be said that the relationship between supportive and moderate organizational climate and workplace incivility is shaped by machiavelist personelity traits. According to this, as the perception of supportive and moderate organizational climate increases for individuals with low machiavelist personality, workplace incivility decreases. However, the precense of supportive and moderate organizational climate for individuals with high machiavelist personality traits also increases workplace incivility. In this sense, the hypotesis of the study " $\mathrm{H} 2$ : Machiavellian personality plays a moderate role between the supporting organizational climate and workplace incivility was accepted. In the literature, there are various studies aimed at determining the relationship between workplace incivility and organizational climate. Among these, Taştan (2014) found a moderate positive and significant relationship between negative organizational climate perception and workplace incivility. Although there are studies indicating that there ise a relationship between workplace incivility and personality traits (Bartlett vd., 2008; Gökçe, 2008; 
Örgüt İkliminin İsyeri Nezaketsizliği Üzerine Etkisinde Makyavelist Kişsilik Özelliklerinin Düzenleyici Rolü

Lewis ve Malecha, 2011; Scheuer, 2010; Shim, 2010; Terlecki, 2011) there is no study on the moderate effect of these features.

Giriş

Emeğin yoğun bir şekilde kendisine yer bulduğu bankacıllk sektöründe çalışanlar, çevresinden büyük oranda etkilenmektedir. Ekonomik ve teknolojik gelişmelerin paralelinde sektör; niteliği, yoğun temposu ve baskı unsurlarının çokluğu nedeniyle saldırgan davranışların gittikçe yoğun görüldüğü bir yapıya dönüşmektedir. Chatman, (1989: 339)'in de belirttiği gibi çalışanın amaçları, değerleri, tutum ve kişiliği olmak üzere birtakım temel özellikleri ile örgütün iklimi, kültürü, değerleri, amaçları ve normları arasındaki benzerliği ifade eden kişi-örgüt uyumu, aynı zamanda çalışanların mutluluk duygularını arttırmaktadır (Demirer, (2019). Sağlıklı insan ilişkilerinin temelini oluşturan bu kavramların örgütsel başarı üzerinde önemli katkıya sahip olduğu gerçeği ile alan yazında birçok araştırmacı, iş yeri nezaketsizliği ile aynı kategoride yer alan zorbalık, yıldırma, saldırganlık, üretkenlik karşıtı iş davranışları vb. kavramları ve bunların örgütsel sonuçlarını irdelemektedir.

Yaşamın her alanında kendisini gösteren saldırgan davranışlar iş hayatında da belirgin bir şekilde artmaktadır. Tarraf(2012) iş yeri nezaketsizliğine mahruz kalan çalışanların dikkatlerinin dağılarak iş performanslarının veya verimliliklerinin düşebildiğini; Kumral (2017) bu çalışanların daha sessiz ve dışlanmış hissettiğini belirtmektedir. Yüceler (2009) ise iş yeri nezaketsizliğine maruz kalan çalışanların örgütsel bağl11ıklarının düşerek; işten ayrılma niyetlerinin artacağını belirtmektedir (Çekmecelioğlu 2005). Yine kavramın iş tatmini, iş doyumu, işten ayrılma niyeti, örgütsel güven, örgütsel adalet, sosyal kaytarma, tükenmişlik vb. birçok örgütsel sonuç ve süreci etkileyebildiği yapılan araştırmalarla ortaya konmuştur (Blau ve Andersson 2005; Kanten, 2014; Kirk vd., 2009; Laschinger vd., 2009; Lewis ve Malecha, 2011; Lim vd., 2008; Penney ve Spector 2005; Polatçı ve Özçalık, 2013).

Günümüzde nitelikli çalışanlar örgütlerin önemli kaynakları arasında yer almaktadır. Bankacılık gibi insan ilişkilerinin yoğun şekilde gerçekleştĭgi hizmet işletmelerinde insan kaynağ daha da önemli hale gelmektedir. Doğru yetenek ve niteliklerdeki insan kaynağına sahip örgütlerde, çalışanlar örgütün diğer örgütlerden ayrılmasına katkı sağlayarak, müşteriler ile bağ kurulmasında önemli bir rol üstlenebilmektedir. Çağın istek ve beklentilerindeki değişimler sadece müşteri ihtiyaçlarının giderilmesinin ötesine geçmiş bulunmaktadır. Artık hizmet alanlar çalışanlarla bağ kurma ve onlara güvenme isteğindedir. Bu bağın ve sinerjinin oluşmasında ise bir organizasyonu diğerlerinden ayıran ve bireylerin davranışları üzerinde etkili olan örgütün psikolojik ortamını ifade eden örgüt iklimi büyük önem arz etmektedir. İşcan ve Karabey (2007) örgüt ikliminin, iş hayatının karakterini ortaya çıkaran duygu ve tutumları içeren, çalışanların çeşitli uygulamalara ve yöneticilerin davranışlarına ilişkin algılamaları sonucu oluşan psikolojik bir çevre olduğunu belirtmektedir. Örgütsel ve yönetsel anlamda var 
olan psikolojik ortam ve örgütsel yaşamın kalitesinden memnuniyet duyan çalışanların birbirleri ile kuracakları olumlu ilişkiler verilen hizmetin kalitesine de yansıyacaktır. İş yerinde yöneticiler ve arkadaşları tarafindan desteklenen, mutlu, huzurlu ve kaliteli bir örgütsel ortamın yaratılması ile çalışanların daha katılımc1, yaratıc1 ve üretken olacakları düşünülmektedir. Ancak örgüt içinde olumlu, katılımcı, destekleyici ve 1lımlı bir örgüt ikliminin yaratılması büyük bir enerji ve emeği gerektirmektedir. Örgütsel bir takım unsurlar, işin çevresi ve koşulları, yapılan işin niteliği, yönetsel ve kültürel bir takım öğeler örgüt içinde algılanan iklimi olumsuzlaştırabilmektedir.

Rekabetin ve insan ilişkilerinin yoğun olduğu bankac1lık sektörü; yoğun iş temposu, uzun çalışma saatleri, çalışanlar arası güç oyunları vb. unsurlar ile yüksek stres ve kaygı içeren bir sektördür. Bu noktada çalışanlar arasında sıklıkla saygı kurallarının ihlal edildiği, bireylerin iş arkadaşları ve yöneticileri tarafından aşağılanarak küçümsendiği durumlar oluşabilmektedir. İşyeri nezaketsizliğinin tanımlanmasında kullanılan bu davranışların ortaya çıkmasında kişilik özelliklerinden; bireyin kendi çıkar ve başarıları doğrultusunda herşeyi yapabileceği (Nelson ve Quick, 1997) felsefesini benimseyen makyavelizmin nasıl bir rol üstlendiğinin belirlenmesi bu araştırmanın çıkış noktasını oluşturmaktadır. Bireyin amaç ve hedefleri doğrultusunda diğer çalışanları manipüle ettiği, gerçekleri yönlendirerek amaca giden her türlü yolu mübah olarak tanımladığı kişilik özelliği olan makyavelizmin, destekleyici ve 11 ımlı örgüt iklimi ile örgüt içindeki nezaket dışı davranışlar arasındaki ilişkide nasıl bir rol üstlendiğinin belirlenmesinin yönetici ve uygulayıc1lara önemli bilgiler sağlayacağı düşünülmektedir. Bu bağlamda söz konusu çalışmada örgütlerin kendilerine has özelliklerini yansıtan destekleyici ve 1 lıml örgüt ikliminin yıkıcı ve istenmeyen davranışlardan iş yeri nezaketsizliği üzerine etkisinin; yine bu ilişkide makyavelist kişilik özelliklerinin nasıl bir rol üstlendiğinin belirlenmesi amaçlanmıştır.

\section{1. Örgüt İklimi}

\section{Kavramsal Çerçeve}

İklim, bir örgütte var olan koşulları, örgütsel yaşam kalitesi ve çalışanların algıladıkları şekli temsil eder (Dönertaş, 2008). Buradan yola çıkarak iklimi, organizasyon çalışanları arasındaki ilişkinin kalitesini belirleyen ve örgütü psikolojik olarak açıklayan bir kavram şeklinde tanımlamak mümkündür (Büte, 2011: 172). Alan yazında iklim örgüt üyelerinin örgütün iç ve dış çevresini ne şekilde değerlendirdiğini ifade eder (Büte, 2011: 172; Haller, 1971: 27). Örgüt iklimi çalışma çevresinin ortamını ve koşullarını yansıtan (Eren ve Çekmecelioğlu, 2002: 887) örgüt ile ilgili bir dizi özelliklerden oluşmaktadır (Arslan, 2004). Schein (1992)' a göre örgüt iklimi çalışanların örgüt hakkında genel algılarıdır ve bu algılar çalışan davranışları üzerinde de etkilidir (Aydoğan, 2004: 10).

Örgüt iklimi işletme içindeki "hava" (Çırpan, 1999: 14) ya da "psikolojik iklim" olarak çeşitli şekillerde adlandırılmaktadır (Shalley vd., 2000). Yukarıda 
Örgüt İkliminin İsyeri Nezaketsizliği Üzerine Etkisinde Makyavelist Kişsilik Özelliklerinin Düzenleyici Rolü

değinildiği gibi algısal bir kavram olan örgüt iklimi (Pritchard ve Karasick, 1973) Yüceler (2009) tarafından aktarıldığ üzere örgütün kişiliğini oluşturan, onu diğer örgütlerden ayıran, tanımlayan, örgütün tümüne yayılan, sürekli, kararlı ve değişmez iç çevreye sahip, örgüt içi bireylerin davranışlarından etkilenen ve onları etkileyen, soyut ve psikolojik bir kavram olarak ifade edilmiştir (Genç ve Karcioğlu, 2000: 24).

Her örgütün kendine özgü bir kültürü ve iklim tipi bulunmaktadır (Arslan, 2004: 221). Bu iklim tipleri ise farklı araştırmacılar tarafindan farklı şekillerde gruplandırılmıştır. Örneğin; Litwin ve Stringer (1968) liderlik özelliklerini esas alarak yaptıkları araştırma sonucunda örgüt iklimi tiplerini; otokratik, demokratik ve başarıya yönelik olmak üzere üç grupta toplamıştır. Araştırmacılara göre otokratik yapılı örgüt ikliminde resmi yapının devamlılığı yönetici tarafindan önemle vurgulanmaktadır. Bu yapılar emir-komuta ağırlıklı olup, rolleri tanımlanmış ve üst düzey performans göstermekle yükümlü üyelere sahiptir. Emir ve cezaların var olduğu bu iklim tipinde çalışanların iş tatmininin düşmesi beklenir. Demokratik yapılı örgüt iklimlerinde ise çalışanların ve yöneticilerin takım çalışmasına yatkınlığı sonucunda örgüt içinde takım ruhu ve işbirliği hakimdir. Bu iklimin hakim olduğu örgütlerde çalışanların kararlara katılımı ve ceza yerine teşviklerin ön planda olması iş tatminlerini yükselten faktörlerdir. Verimliliğe üst düzeyde önem verilen başarıya yönelik iklim tipinde çalışanlar sorumluluk alma, yaratıcılık ve yenilikçilik konularında cesaretlendirilir. Cezalandırmanın olmadığı, ödül, terfi ve prim sisteminin var olduğu bu iklim tipinde resmi olmayan iletişim hakimdir (Halis ve Uğurlu, 2008: 107-108).

Örgüt iklimi konusunda çalışan bir diğer araştırma grubu Shadur vd. (1999)'dir. Araştırmacılar örgüt iklimini destekleyici, yenilikçi ve bürokratik olarak üç tipte incelemişlerdir. Yöneticilerin serbest hareket edebildiği destekleyici iklim tipinde üst kademe çalışanlar alt kademe çalışanların duygu ve düşüncelerine önem vermektedir. Aynı zamanda yeni icat ve deneyimlere açık olan örgüt, yönetici konumundaki kişilerden güncel gelişme ve bilgelerin öğrenilmesi konusunda talepte bulunmaktadır (Baumgartel vd., 1984). Shadur vd. (1999)'den aktarıldığı üzere sonuç odaklı olan yenilikçi iklim tipini örgüt üyelerini risk almaya teşvik eden, yaratıcı, girişimci ve harekete geçirici olarak tanımlamak mümkündür (Menemencioğlu, 2018: 98). Otokratik iklim tipine benzediği düşünülen bürokratik iklim tipi ise Shadur vd. (1999) tarafindan prosedürlere, kurallara bağlı ve güç odaklı olarak tanımlanmıştır. Ayrıca resmi bir ortamın bulunduğu bu iklim tipinde çalışanların tam katılımının mümkün olmadığ söylenebilir (Menemencioğlu, 2018: 98).

Halphin (1966)'e göre ise açık iklim, kapalı iklim, babacan iklim, samimi iklim, bağımsız iklim ve kontrollü iklim olmak üzere toplam altı örgüt iklim tipi bulunmaktadır. Yönetici ve çalışanların büyük bir uyum içinde olduğu açık iklim tipinde, yöneticiler eleştirilere açık, çalışanlarda görevlerini yerine getirme konusunda oldukça isteklidir. Buna karşın kapalı iklim tipinde yöneticilerin emirler verdiği ve çalışanlar arası ilişkilerin samimi olmadığını söylemek 
mümkündür. Benzer şekilde babacan iklim tipinde çalışanlarını kontrol etmek isteyen yöneticiler ve samimiyetten uzak bir örgüt yapısı bulunmaktadır. Yöneticinin kendisini bir personel gibi gördüğü, son derece anlayışlı olduğu iklim tipi ise adından da anlaşılabileceği gibi samimi iklim tipidir. Son iklim tipi olan kontrollü iklimde ise anlayışsız, emir verici ve göreve son derece önem veren yöneticilerin var olması sonucunda çalışanların iş yapmak dişında sosyal ilişkilere ayıracak zamanları yoktur (Arslan, 2004).

Kavramın açıklanması ve yorumlanmasını kolaylaştırmak adına farklı araştırmacılar tarafindan farklı şekillerde incelenen kavramın boyutları da değişiklik göstermektedir. Örneğin Campbell vd. (1970) örgüt iklimini bireysel özellik, durumsal örgütsel yapı, ödül yönetimi, saygınlık, yatkınlık ve destek olarak alt1 farklı boyutta incelerken; James ve James. (1989) rol stresi ve uyum eksikliği, işin cazip olması ve özerklik, liderlik ve lider desteği, çalışma grubu işbirliği ve yatkınlığı olarak dört boyutta ele almıştır (Ertuğrul ve Özçelik, 2018). Patterson vd. (2005: 385-386) örgüt iklimini çalş̧an mutluluğu, özerklik, katılımc1lık, iletişim, eğitime önem verme, entegrasyon ve yönetici desteği olmak üzere yedi farklı boyutta incelemiştir. Kaya vd. (2010: 2034-2035) ise kavramı yaratıcılık için destek, yönetim yeteneği ve tutarlılık, iş yükü baskısı, örgütsel sinırlar, uyum ve örgütsel etik olarak altı boyutta ele almıştır.

Örgütün psikolojik ortamını ifade eden kavram örgütsel birçok süreç ve sonuç üzerinde etki ve güce sahiptir. İş ortamındaki faktörleri keşfederek geliştirmeye ve çalışanı daha istekli hale getirerek performansını artırıp buna bağlı olarakta üretimin artmasını sağlayan örgüt iklimi (Arslan, 2001: 206) iş ortamında, çalışan davranışlarında ayrıca yenilik ve yaratıcılık üzerinde etkilidir (Shalley vd., 2000). Mullins (1993) örgüt ikliminin çalışan performansını, kişisel ilişkilerini ve tutumlarını etkilediğini belirtmektedir (Mullins, 1993: 651). Yapılan araştırmalarda örgüt ikliminin duygusal bağlılığı (Çekmecelioğlu, 2006), fiziksel çalışma koşulları üzerinde ise örgütsel bağl1lığ̣ pozitif yönde etkilediği belirtilmiştir (Yüceler, 2009). Kavramı araştırma konusu eden çalışmalardan bazıları lider-üye etkileşimi (Kozlowski ve Doherty, 1989), makyavelizm (Karcıoğlu, 2001), işten ayrılma niyeti ve iş tatmini, performans ve yaratıcılık (Çekmecelioğlu, 2005), yeniliğe destek algısı (İşcan ve Karabey, 2007), örgütsel bağll1ık (Yüceler, 2009), çalışan memnuniyeti (Castro ve Martins, 2010) ve mobbingtir (Alay, 2016).

\section{2. İ̧s Yeri Nezaketsizliği}

Nezaket başkalarına saygılı olmayı ve diğer kişilerin duygularına göre davranmayı, sosyal normların da karşılıklı olarak saygı içinde muhafaza edilmesini kapsarken (Andersson ve Pearson, 1999: 453) nezaket dışı davranışlar karşı1ıklı saygı kurallarını ihlal etmek, kişileri küçümsemek ve onları aşağılamak gibi davranışları içinde barındırmaktadır (Dion, 2006: 11). İlk kez Andersson ve Pearson (1999) tarafından ortaya atılan kavram üretkenlik karşıtı iş davranışları içerisinde yeni bir alan olarak ele alınmış (Işıkay, 2018: 7) ve taciz, iş istismarı, 
Örgüt İkliminin İsyeri Nezaketsizliği Üzerine Etkisinde Makyavelist Kişsilik Özelliklerinin Düzenleyici Rolü

kabalık, kötü muamele ve zorbalık gibi çeşitli kavramlar ile ilişkilendirilmiştir (Gökçe, 2008). Ayrıca iş yeri nezaketsizliğine Martin (1996)'e göre telefon görüşmesi esnasında teşekkür etmeyi ihmal etmek, iş arkadaşı telefon görüşmesi yaparken yanında durmak, temizleyen var diye yere çöp atmak, kişisel konularda telefonda konuşurken sesini yükseltmek gibi örnekler vermek mümkündür (Andersson ve Pearson, 1999: 453). Yine Carter (1998)'a göre resmi görgü kurallarına uymak saygı duyarlılığından, ilgi alakadan ve kibar olmaktan daha az nezaketle ilgilidir.

Bazı araştırmacılara göre çalışanların nezaketsiz ve diğer agresif iş yeri davranışlarını artıran nedenler (Baron ve Neuman, 1996, akt: Andersson ve Pearson 1999: 453) arasında; verimlilik için çalışanlar üzerinde artan bask1, çalışan çeşitliliği, bütçe kesintileri, otokratik çalışma ortamı ve part-time çalışanlar yer almaktadır. İşyerinde nazik davranışlar benzer iş yeri davranışlarından ve diğer davranışlardan ayırt edilebilir. Nazik olmayan davranışlar görgü kurallarının ihlal edilmesinden profesyonel suistimallere, genel huzursuzluktan ahlaki bozulmaya kadar herşeyle ilgilidir (Carter, 1998; Gladwell, 1996; Johnson, 1988; Martin, 1996; Roberts, 1985). Andersson ve Pearson (1999: 546) iş yerinde nezaketsizlik ve diğer kötü davranış türlerini beşe ayırmıştır;

- Sosyallik karşıtı davranışlar; organizasyon ya da üyelerine zarar veren davranışlar (antisocial behavior),

- Sapkın davranışlar; normları ihlal eden sosyallik karşıtı davranışlar (aggression),

- Şiddet; yüksek yoğunluklu fiziksel olarak agresif davranışlar (violance),

- Saldırganlık; zarar verme niyeti ve sapkın davranışlar (aggression),

- Nezaketsizlik; düşük yoğunluklu sapkın davranışlar ile belirsiz zarar verme niyetidir (incivility).

İş yeri nezaketsizliğini önlemek adına sağlıklı bir çalışma ortamının yaratılması ve bu ortamın devamlılığının sağlanması önem arz etmektedir (Lewis ve Malecha, 2011; 41). Pearson ve Porath (2005)'dan aktarıldığı üzere örgütte nezaket dışı davranışlara hoşgörü gösterilemeyeceği devamlı olarak yazılı ve sözlü biçimde vurgulanmalıdır. Yine örgüt içinde çalışanların karşılıklı olarak birbirlerine ne şekilde davranmaları gerektiğini gösteren yazılı ifadelerin yer aldığı kararlar oluşturulmalı ve uygulanmalıdır (Kumral, 2017: 14-15).

Yapılan araştırmalarda iş yeri nezaketsizliğinin iş tatminini (Cortina vd., 2001; Pearson ve Porath, 2005; Penney ve Spector, 2005), örgütsel sadakati (Pearson ve Porath, 2005), örgütsel etkililiği (Laschinger vd., 2012: 317) ve örgütsel bağlılığı (Hossny vd., 2015), negatif yönde etkilediği tespit edilmiştir. Buna karşın iş yeri nezaketsizliğinin pozitif ilişkide olduğu kavramlardan bazıları tükenmişlik (Polatcı ve Özçalık, 2013), sosyal kaytarma davranışı, duygusal tükenme, işten ayrılma niyetidir (Kanten, 2014). 


\subsection{Makyavelist Kişilik Özelliği}

Makyavelizm, 16. Yüzyılda Niccolo Machiavelli tarafından ortaya atılmıştır. Niccolo Machivelli (The Price) "Prens" adını verdiği içerisinde taktiklerin, tutumların ve çeşitli strajilerin yer aldığı eserinde bireyin gücünü kullanarak nasıl istediği amaçları elde edeceğini anlatmaktadır (Ayan, Ünsar ve Kahraman, 2013: 104-105; Ayan, 2017: 54). Machiavelli'ye göre prens iktidarlığını sürdürebilmek için iç ve dış tehditlere karşı güçlü olmalı bunun yanı sıra aslında iyi, anlayışl, insancıl olmasına rağmen yeri geldiğinde de ters şekilde davranmasını bilmelidir (Machiavelli, 1532, çev. Gündüz, 2003: 7 akt: Sabur, 2011: 48).

Suçluluk ve aldatma ile eş anlamlı olan ve Machiavelli tarafindan alan yazına kazandırılan Makyavelizm felsefesinin temeli; amaca ulaşmada kullanılan ya da kullanılacak olan her türlü yolun mübah olduğu düşüncesidir. Yine amaçlara ulaşmak için kullanılacak araçlarında ahlaki olduğu düşünülmektedir. Çünkü bu araçlar ahlaki ya da hukuki açıdan sınırlandırılmamıştır (Geis and Moon, 1981; Machiavelli, 2000: 7-8, akt: Güney ve Mandac1, 2009: 84).

Alan yazında makyavelizm ile ilgili birçok tanıma yer verilmiştir. Christie ve Geis (1970) makyavelizmin sosyal bir etki süreci olduğunu vurgalayarak makyavelizmde amaçlara ulaşmak uğruna güç ve politik davranışların kullanıldığını belirtmektedir. Guterman (1970) makyavelizmin hem diğer insanlar üzerinde kalıcı ve o insanları yönlendirici etkiye sahip olduğunu, hem de ahlaki davranışlardan uzak olduğu belirtilmektedir. Nelson ve Quick (1997) kavramı kişinin istediği yönde ve şekilde hareket etmek uğruna her şeyi yapmak için hazır olması şeklinde tanımlamıştır. Robbins (1998)'in yapmış olduğu tanıma göre makyavelizm kişinin pragmatik oluşu ve duygusal anlamda belirleyebildiği mesafe ve buna bağlı olarak ulaşmayı arzuladığı sonuçların yollarını mübah kıldığına inanma derecesidir. Ang (2000) makyavelist bireyin başkalarını rahatlıkla kullanabildiğini ayrıca bunu kendi çıkar ve başarısı doğrultusunda yaptığını savunmuştur (Güney ve Mandacı, 2009: 84). Yine alan yazındaki tanımlarda, kişiliğin karanlık yönü olarak nitelendirilen makyavelizm, narsizm ve psikopatlığında bulunduğu karanlık üçlü içinde yer almıştır (Kutanis vd., 2015; Paulhus ve Williams, 2002; Uçkun vd., 2018).

Kavramı alan yazına kazandıran Christe ve Geis (1970) kişisel bir özellik olan makyavelizmin bireysel bir farklılık olduğunu iddia etmiş aynı zamanda makyavelizm düşüncesinin uluslararası geçerliliği olduğunu da vurgulamıştır (Özsoy ve Ardıç, 2017: 395). Bu kişilik özelliğini daha net anlamak için barındırdığı birtakım özelliklere bakıldığında bu özellikler; kendi çıkarları söz konusu olduğunda çekinmeden yalana ya da hileye başvurabilmek, soğukkanlılık, empati eksikliği, ikiyüzlülük ve samimiyetsizlik, insanları yönetebilmek adına onlardan gerçeği saklamak, kendi amaç ve çıkarları doğrultusunda başka kişileri veya koşulları manipüle etmek, kendi güçsüz yönlerini saklayıp başkalarınınkini ortaya çıkarmak ve en önemli özelliklerinden 
Örgüt İkliminin İsyeri Nezaketsizliği Üzerine Etkisinde Makyavelist Kişsilik Özelliklerinin Düzenleyici Rolü

biri olan her yerde herkese herşeyi söylememek (Jones ve Paulhus, 2009: 96) olarak sayılabilir.

Alan yazında makyavelist kişilik özelliği ile birçok konu beraber incelenmiş olup bu araştırmalar ve sonuçları şu şekildedir: Makyavelizm ve etik arasında (Güney ve Mandacı, 2009), yine makyavelizm ile yakın olduğu düşünülen narsisizm (Paulhus ve Williams, 2002) ve iş tatmini arasında negatif ilişkiler tespit edilmiştir (Özsoy ve Ardıç, 2017). Benzer şekilde Demirtaş ve Biçkes (2014) tarafından makyavelizmin ifşa niyeti üzerine negatif etkisi tespit edilmiştir. Kavram ile demografik değişkenler birlikte incelendiğinde ise farklı sonuçlar ortaya çıkmıştır. Bazı araştırmalar demografik anlamda herhangi bir farklılaşmanın bulunmadığını (Aydoğan ve Serbest, 2016) belirtirken bazı araştırmalar demografik özelliklere göre makyavelist kişilik özelliğinin değiştiğini (Özer vd., 2016) belirtmektedir.

\section{Araştırma Hipotezleri ve Modeli}

Değişen çalışma koşulları ile birlikte önemli bir değer haline dönüşen insan kaynağının farklılaşan ihtiyaçları ve beklentileri, çelişen amaç ve istekleri örgüt içinde saldırganlık ve öfke içeren mobing, üretkenlik karşıtı davranışlar, sabotaj ve nezaket dışı davranışların ortaya çıkmasına neden olmaktadır. Yapılan araştırmalarda belli bir amaç doğrultusunda zarar verme niyeti belirsiz, düşük yoğunluklu sapma davranışları olarak tanımlanan nezaketsiz davranışların giderek artmakta olduğu tespit edilmiştir (Bulutlar ve Öz, 2009; Çangarlı, 2009; Gültaç, 2019; Johnson ve Indvik, 2001; Leymann ve Gustafsson, 1996; Yücetürk ve Öke, 2005; Zapf vd., 1996).

Başkalarına karşı saygısız ve umursamaz davranma, kişilerarası ilişkilerde saygı normlarını yerine getirmeme olarak tanımlanan nezaketsizlik davranışı (Anderson ve Pearson, 1999: 452-471) bireysel ve örgütsel açıdan birçok sonucu beraberinde getirmektedir. Yapılan araştırmalarda iş yeri nezaketsizliği ile örgütsel güven (Cingöz ve Kaplan, 2015); sosyal kaytarma, duygusal tükenme ve işten ayrılma niyeti ile pozitif ve anlaml ilişkiler tespit edilmiştir (Kanten, 2014; Laschinger vd., 2009). Polatçı ve Özçalık (2013) ve Blau ve Andersson (2005) iş yeri nezaketsizliği algısının tükenmişliği artırdığını, Miner vd. (2012) ise iş yeri nezaketsizliğinin iş stresi ve depresyonu artırarak iş tatminini ve yaşam doyumunu azalttığını belirtmiştir. Yine yapılan araştırmalarda iş yeri nezaketsizliği ile verimlilik (Lewis ve Malecha, 2011) iş tatmini (Blau ve Andersson 2005; Kirk vd., 2009; Laschinger vd., 2009; Lim vd., 2008; Penney ve Spector 2005), örgütsel bağl1lık ve dağıtım adaleti (Blau ve Andersson, 2005) arasında negatif ilişkilerin olduğu görülmüştür (Laschinger vd.,2009).

Örgütsel kültür ve yönetimin felsefesiyle (Simmons, 2008) yakından ilişkili olan iş yeri nezaketsizliği aynı zamanda örgüt iklimi ile de yakın ilişki içindedir (Jacobson, 2007; Scheuer, 2010; Shim, 2010; Soljan vd., 2009). İşyeri nezaketsizliği örgüt içinde öfke-şiddet içeren davranışların sergilenmesi ile birlikte çalışanları iş doyumu ve güven düzeylerini düşürerek örgüt iklimini 
olumsuz şekilde etkilemektedir (Delen, 2011; Shim, 2010). Taştan (2014) iş yeri nezaketsizliğini öngören örgütsel ve durumsal önceller ile çalışanların davranışsal sonuçları arasındaki ilişkiyi ve sosyo-psikolojik kaynakların rolünü incelemek üzere gerçekleştirdiği çalışmasında olumsuz örgüt iklimi ile iş yeri nezaketsizliği arasında orta düzeyde pozitif ve anlamlı ilişkiler tespit etmiştir. Shim (2010) ise çalışmasında işbirlikçi örgüt iklimi ve bireysel kişilik özelliklerinin iş yeri nezaketsizliği ve bilgi paylaşım niyeti üzerinde moderatör rol üstlendiğini belirtmektedir. Yine Köse vd. (2014) düzenleyici odaklar ve iş yeri nezaketsizliği ilişkisinde olumsuz örgütsel iklimin düzenleyici etkisini belirlemek üzere gerçekleştirdikleri çalışmada yönelimci odaklılığın ve kaçınmacı odaklılığın iş yeri nezaketsizliği algısı üzerindeki etkisinde örgüt ikliminin düzenleyici etkiye sahip olduğunu tespit etmiştir.

İş yeri nezaketsizliğinin ortaya çıkmasına neden olan faktörleri araştıran çalışmaların bir kısmı kavram ile kişilik özellikleri arasında bir ilişki olduğunu belirtmektedir (Bartlett vd., 2008; Gökçe, 2008; Lewis ve Malecha, 2011; Scheuer, 2010; Shim, 2010; Terlecki, 2011). Örneğin Meier ve Semmer (2012) narsist kişilik özellikleri yüksek olan çalışanlarda öfke ve nezaketsiz davranışlar arasındaki ilişkinin daha güçlü olduğunu tespit etmiştir. Ancak alan yazında makyavelist kişilik özelliği ile örgüt iklimi ya da iş yeri nezaketsiziliği arasındaki ilişkileri belirlemeye yönelik herhangi bir çalışmaya rastlanmamıştır. Bu çalışma ile örgüt içindeki psikolojik durumu ifade eden ve çalışanların yöneticilerinin desteğine ilişkin algılarının örgütsel birçok süreç ve sonuç üzerinde etki ve güce sahip olduğu bilinen destekleyici örgüt iklimi ile iş yeri nezaketsizliği arasındaki ilişkinin belirlenmesinin yanı sıra makyavelist kişilik özelliklerinin bu ilişkideki rolünün belirlenerek alan yazına katkı sağlanması amaçlanmaktadır.

Örgüt üyelerinde iyi duygular uyandıran bir ortam destekleyici (olumlu) örgüt iklimi, bunun tam tersi ise olumsuz örgüt iklimidir. Destekleyici iklimin özellikleri arasında açık ilişkiler, dostluk, iş birliği, cesaret verme, sosyalleşme, kişisel özgürlük ve güven vardır. Örgüt yönetiminin çalışanlarına verdiği destek, örgütsel çabaların merkezindedir. Çalışanların örgüt tarafından desteklendiklerini algılaması ile sorumluluklarını bilinçli bir biçimde yerine getirmeleri, örgütün amaç ve sorunları ile ilgilenmeleri, kişisel beklenti ve ödül olmaksızın örgüt için yenilik gayretine girmeleri arasında, pozitif bir ilişki vardır (Özkul, 2013:15). Bu bağlamda araştırmanın modeli ve hipotezleri aşağıdaki gibidir:

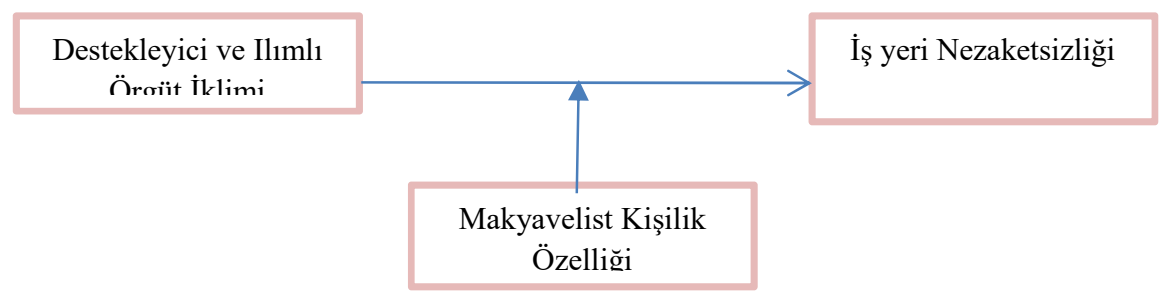

Şekil 1. Araştırma Modeli 
Örgüt İkliminin İsyeri Nezaketsizliği Üzerine Etkisinde Makyavelist Kişsilik Özelliklerinin Düzenleyici Rolü

$\mathrm{H}_{1}$ : Destekleyici ve 1 lımlı örgüt iklimi algısı iş yeri nezaketsizliğini negatif yönlü ve anlamlı olarak etkilemektedir.

$\mathrm{H}_{2}$ : Makyavelist kişilik özelliği destekleyici ve 1 lımlı örgüt iklimi algısı ile iş yeri nezaketsizliği arasında düzenleyici bir rol üstlenmektedir.

\section{1. Örneklem}

\section{Materyal ve Yöntem}

Araştırma evreni Kasım-Mart 2018 tarihlerinde Kayseri ve Eskişehir il merkezinde faaliyet gösteren özel ve kamu banka çalıșanlarından oluşmaktadır. Belirtilen dönem içinde Kayseri il mezkezinde faaliyet gösteren 11 banka şubesinin toplam çalışan sayısı 146; Eskişehir için 10 farklı banka şubesinin toplam çalışan sayıs1 208 olarak belirlenmiştir. Araştırma için örneklem belirlenmeyerek evrenin tamamına ulaşılması hedeflenmiştir. Bu doğrultuda 354 anket dağıtılmış, bu anketlerden 198 tanesi geri dönmüş ancak 187 tanesi analizler için uygun bulunmuştur. Araştırma için kullanılacak verilerin toplanması sırasında hazırlanan anket formunun uygulanabilirliği, sorular ve formun anlaşılırlığının test edilmesi amacıyla örneklemden seçilen 65 çalışana pilot bir uygulama yapılmıştır. Pilot uygulama sonucunda her bir ifadeye ait cevaplar ile toplam ölçek skorları arasındaki ilişkiler belirlenmiştir. Bu verilerle yapılan analizlerde, geçerlik ve güvenirlik testleri yapılmış ve ölçeğin anlaşılabilirliği gözden geçirilmiştir.

\subsection{Veri Toplama Araçları}

Araştırmada kullanılan veriler anket yöntemi ile toplanmıştır. Çalışanların destekleyici ve 1lımlı örgüt iklimi algılarını ölçmek için Robert Stringer (2002) tarafından geliştirilen Örgüt İklim Ölçeği'nin destek ve 1lımlılık boyutu, iş yeri nezaketsizliğini ölçmek için Cortina vd. (2001) tarafından geliştirilen "İş yeri Nezaketsizliği Ölçeği” ve makyavelist kişilik özelliğini ölçmek üzere Dahling vd. (2009) tarafından geliştirilen "Makyavelizm Ölçeği”" kullanılmıştır. Örgüt İklimi Ölçeğinin destek alt boyutu 5 , 1 lımlılık alt boyutu ise 4 ifade, İş yeri Nezaketsizliği Ölçeği 7 ifade ve tek boyuttan ve Makyavelizm Ölçeği 16 ifade ve 4 boyuttan oluşmaktadır. Çalışmada 5'li likert tipi ölçek kullanılmıştır. Ayrıca anketin son kısmında katılımcıların demografik özelliklerini belirlemeye yönelik sorular yer almaktadir.

Araştırmada kullanılması planlanan ölçeklerin yapı geçerliliğini ëlȩmek belirlemek üzere her bir ölçek için ayrı ayrı açıklayıcı (AFA) ve doğrulayıcı faktör analizi (DFA) yapılmıştır. Araştırmada kullanılan destekleyici ve 1lımlı örgüt iklimi algısı, iş yeri nezaketsizliği ve makyavelizm ölçeklerinin yapısal geçerliliğini belirlemek amacıyla AFA uygulanmıştır. Analiz sonucunda KaiserMeyer-Olkin Testinin (KMO) değeri destekleyici ve 1lımlı örgüt iklim ölçeği için .856, iş yeri nezaketsizliği ölçeği için .786 ve makyavelizm için .834 olarak tespit edilmiştir. Bu değer örneklem büyüklügünün faktör analizi için uygun (Çokluk vd., 2012) olduğunu göstermektedir. Bartlett küresellik testi sonuçları incelendiğinde ise destekleyici ve 1lımlı örgüt iklimi, $\left(X^{2}=639,674, p<0,00\right)$, iş 
yeri nezaketsizliği $\left(\mathrm{X}^{2}=764,895, \mathrm{p}<0,00\right)$ ve makyavelizm ölçeği için $\left(\mathrm{X}^{2}=1529,644, \mathrm{p}<0,00\right)$ ki-kare değerinin anlamlı olduğu bulgulanmıştır.

Destek boyutunda yer alan bir ifade güvenirliliği düşürmesi nedeniyle açılayıcı faktör analizine dâhil edilmemiştir. 4 ifade ile yapılan analiz sonucunda destek boyutunu ölçtüğü düşünülen 1 ifadenin daha sınır değerin olan .30'un altında kaldığı görülmüştür. İfadenin analizden çıkarılarak tekrar edilmesi sonucunda ise destek ve 1lımlılık boyutlarıtek bir faktör altında birleşmiştir. Yapılan analizler sonucunda ölçeğin bu çalışma için özdeğeri 1'den büyük tek bir faktörden oluştuğu ve bu faktörün toplam varyansın $\% 51,855$ 'ini açıkladığı tespit edilmiştir. İşyeri nezaketsizliği ölçeği için yapılan AFA sonucunda ölçeğin 7 maddelik ve tek faktörlü yapısı doğrulanmıştır. Özdeğeri 1'in üzerinde elde edilen tek boyutun toplam varyansın \% 51,755' lik kısmını açıkladığı görülmüştür. Yine makyavelist kişilik özelliğini ölçmek üzere kullanılan makyavelizm ölçeği için yapılan AFA sonucunda 13 ifadelik 2 boyut saptanmıştır. Bu boyutlardan 9 ifade ahlaki yoksunluk boyutunu ölçerken, kalan 5 ifade ise diğerlerine güvensizliği ölçmektedir. Elde edilen bu boyutlardan ilki toplam varyansın \%55,190'ını açıklarken ikinci boyut \%41,377'lik kısmını açıklamaktadır.

Yine araştırmada kullanılan ölçek yapılarının sınanması amacıyla yapısal eşitlik modellemesinden (YEM) yararlanılmıştır. Alan yazında DFA için sıklıkla kullanılan uyum iyiliği değerlerinin $\left(\chi^{2} / \mathrm{df}\right)$ Ki-Kare Uyum Testi, (IFIIncremental Fit Index) Artırmalı Uyum Indeksi, (CFI- Comparative Fit Index) Karşılaş̧tırmalı Uyum İndeksi, (NFI- Normed Fit Index) Normlandırılmış Uyum İndeksi, (GFI- Goodness of Fit Index) Uyum İyiliği İndeksi ve Yaklaşık Hataların Ortalama Karekökü (RMSEA- Root Mean Square Error of Approximation) olduğu görülmektedir (Browne ve Cudeck, 1993; Byrne, 2001; Çokluk vd., 2012; Kline, 2005; Marsh vd., 1988a; Marsh ve Hocevar, 1988b; Sümer, 2000; Şimşek, 2007; Tabachnick ve Fidell, 2007). Yapılan birinci düzey DFA sonras1 araştırmanın değişkenlerine ilişsin uyum indeksi değerleri tablo 1'de yer almaktadır.

Tablo1. Değişsenlere İlişkin Doğrulayıcı Faktör Analizi

\begin{tabular}{|l|c|c|c|c|c|c|c|c|c|}
\hline Ölçek/ İndeksler & $\boldsymbol{\chi}^{\mathbf{2}}$ & $\mathbf{d f}$ & $\mathbf{p}$ & $\boldsymbol{\chi}^{\mathbf{2} / \mathbf{d f}}$ & $\mathbf{C F I}$ & GFI & IFI & NFI & RMSEA \\
\hline $\begin{array}{l}\text { Destekleyici ve } \\
\text { Ilımlı Örgüt İklimi }\end{array}$ & 54,054 & 13 & .00 & 4,158 & 0,93 & 0,92 & 0,93 & 0,91 & 0.7 \\
\hline İşyeri Nezaketsizlĭgi & 16,750 & 6 & .00 & 2,79 & 0,96 & 0,96 & 0,96 & 0,96 & 0.8 \\
\hline $\begin{array}{l}\text { Makyavelist Kişilik } \\
\text { Özelliği }\end{array}$ & 175,390 & 49 & .00 & 3,579 & 0,90 & 0,87 & 0,91 & 0,90 & 0.7 \\
\hline
\end{tabular}

Destekleyici ve 1 lımlı örgüt iklimi algısını ölçmeye yönelik 7 ifade tek boyutta modellenmiştir. Doğrulayıcı faktör analizinden elde edilen modelin uyum indeksleri incelenmiş ve minimum ki-kare değerinin $(\chi 2=54,054, \mathrm{df}=13$, $\mathrm{p}=0.00$ ) anlamlı olduğu görülmüştür. Uyum indeksi değerleri ise RMSEA=0.07, $\mathrm{CFI}=0.93, \mathrm{GFI}=0.92, \mathrm{IFI}=0.93, \mathrm{NFI}=0.91$ olarak bulunmuştur. Ölçeğin Alfa güvenirlik kat sayıs1 .881 olarak belirlenmiştir. 
Örgüt İkliminin İşyeri Nezaketsizliği Üzerine Etkisinde Makyavelist Kişilik Özelliklerinin Düzenleyici Rolü

İş yeri nezaketsizliği ölçeğinin yapısının doğrulanması amacıyla yapılan DFA sonucu tablo 1'de yer almaktadır. Yine iş yeri nezaketsizliğini ölçmeye yönelik 7 ifade tek boyutta modellenmiştir. Buna göre modelin uyum indeksleri incelenmiş ve minimum ki-kare değerinin $(\chi 2=16.750, \mathrm{df}=6, \mathrm{p}=0.00)$ anlamlı olduğu görülmüsstür. Uyum indeksi değerleri ise $\mathrm{RMSR}=0.8, \mathrm{GFI}=0.96$, $\mathrm{CFI}=0.96, \mathrm{IFI}=0.96, \mathrm{NFI}=0.96$ olarak bulunmuştur. Bu uyum indeksi değerleri tek faktörlü modelin uyumlu olduğunu ortaya koymaktadır. Ölçeğin Alfa güvenirlik kat sayıs1 872 olarak belirlenmiştir.

Yine makyavelist kişilik ölçeği için yapılan DFA sonuçları tablo 1'de yer almaktadır. Tablo 1'e göre modelin uyum indeksleri değerleri; minimum ki-kare değerinin $(\chi 2=175.390, \mathrm{df}=49, \mathrm{p}=0.00)$ anlamlı olduğu görülmüştür. Uyum indeksi değerleri ise $\mathrm{RMSR}=0.7, \mathrm{GFI}=0.87, \mathrm{CFI}=0.90, \mathrm{IFI}=0.91, \mathrm{NFI}=0.90$ olarak bulunmuştur. Bu uyum indeksi değerleri iki faktörlü modelin uyumlu olduğunu ortaya koymaktadır. Ölçeğin Alfa güvenirlik kat sayısı .922 olarak belirlenmiştir.

\section{Bulgular}

Araştırmaya katılanların \%53,5'inin kadın, \%55,1'inin 31-40 yaş aralığında, \%72,7'sinin evli, \%67,4'ünün lisans düzeyinde eğitime sahip olduğu görülmektedir. Yine katılımcıların \%44,4'ünün 10 y1l ve üzeri çalışma deneyimine sahip olduğu tespit edilmiştir.

Tablo 2. Katılimcıların Demografik Özellikleri

\begin{tabular}{|l|l|l|l|l|l|l|}
\hline Deneyim & $\mathrm{N}$ & $\%$ & Yaş & $\mathrm{N}$ & $\%$ \\
\hline 1 y1ldan az & 8 & 4,3 & $20-30$ & 49 & 26,2 \\
\hline $1-5$ & 37 & 20,0 & $31-40$ & 103 & 55,1 \\
\hline $6-10$ & 57 & 30,8 & 41 -üzeri & 33 & 17,6 \\
\hline 10 -üzeri & 83 & 44,9 & Medeni Durumu & $\mathrm{N}$ & $\%$ \\
\hline Eğitim Düzeyi & $\mathrm{N}$ & $\%$ & Evli & 136 & 72,7 \\
\hline Lise & 14 & 7,5 & Bekar & 49 & 26,2 \\
\hline Önlisans & 29 & 15,5 & Cinsiyet & & \\
\hline Lisans & 126 & 67,4 & Kadın & 100 & 53,5 \\
\hline Master/Doktora & 16 & 8,6 & Erkek & 85 & 45,5 \\
\hline
\end{tabular}

Araştırmanın değişkenleri olan destekleyici ve ılımlı örgüt iklimi algısı, makyavelist kişilik özelliği ve iş yeri nezaketsizliği arasındaki ilişkiler ve bu ilişkilere ait standart sapma ve ortalama değerler ise Tablo 3'te yer almaktadır.

Tablo 3. Ortalama, Standart Sapma ve Korelasyon Değerleri

\begin{tabular}{|l|l|l|l|l|l|}
\hline & Ort. & s.s. & $\mathbf{1}$ & $\mathbf{2}$ & $\mathbf{3}$ \\
\hline 1.Destekleyici ve Ilımlı Örgüt İklimi & 3,49 &, 78 & 1 & & \\
\hline 2.İşyeri Nezaketsizliği & 2,20 &, 81 &,$- 40^{* *}$ & 1 & \\
\hline 3.Makyavelist Kişilik Özelliği & 2,94 &, 87 &,$- 07 *$ & $0,22^{* *}$ & 1 \\
\hline
\end{tabular}

* İlişkinin \%5; ** ilişkinin \%1 düzeyinde anlamlı olduğunu göstermektedir $(\mathrm{p}<0.01$; $\mathrm{p}<0.05)$. 
Tablo 3 incelendiğinde destekleyici ve 1 lımlı örgüt iklimi algısı ile iş yeri nezaketsizliği $(\mathrm{r}=-0,40$ ve $\mathrm{p}<0.01)$ ve makyavelist kişilik özelliği $(\mathrm{r}=0,06$ ve $\mathrm{p}<0.05$ ) arasında anlamlı ve negatif yönlü ilişkiler tespit edilmiştir. Yine makyavelizm ile iş yeri nezaketsizliği arasında $(\mathrm{r}=0,22 ; \mathrm{p}<0,01)$ pozitif yönlü bir ilişki görülmüştür. Değişkenlere ait ortalamalar incelendiğinde örgüt iklimi $(3,49)$ ve makyavelist kişilik özelliğine $(2,85)$ ilişkin skorlar ortalamanın üzerinde, iş yeri nezaketsizliği $(2,20)$ skorları ise ortalamanın altında değerler almıştır.

Araştırmada, destekleyici ve 1lımlı örgüt iklimi algısının iş yeri nezaketsizliğine etkisinde makyavelist kişilik özelliğinin düzenleyici etkisini belirlemek üzere iki hipotez geliştirilmiş olup bu hipotezleri test etmek amaciyla çoklu regresyon analizi yapılmıştır. Bu doğrultuda oluşturulan hipotezlerin test edilmesi adına yapılan analizler ve analiz bulguları ise Tablo 4'te yer almaktadır.

Tablo 4. Hiyerarșik Regresyon Analizi Bulguları

\begin{tabular}{|c|c|c|c|c|c|}
\hline \multirow[t]{2}{*}{ Model } & \multicolumn{4}{|c|}{ Regresyon Katsayıları } & \multirow[t]{2}{*}{ Model İstatistikleri } \\
\hline & B & S.H. & $\bar{\beta}$ & $\mathbf{t}$ & \\
\hline $\begin{array}{l}\text { (Sabit) } \\
\text { Destekleyici ve } \\
\text { Ilımlı Örgüt İklimi }\end{array}$ & $\begin{array}{l}3,651 \\
-, 414\end{array}$ & $\begin{array}{l}, 252 \\
, 070\end{array}$ &,- 400 & $\begin{array}{l}14,514 \\
-5,900\end{array}$ & $\begin{array}{l}R=, 400 ; R^{2}=, 160 ; F_{(1,183)}=34,809 ; \\
p=.000\end{array}$ \\
\hline 2 (Sabit) & 3,189 & ,290 & & 11,001 & \multirow{3}{*}{$\begin{array}{l}R=, 447 ; R^{2}=, 200 ; F_{(2,182)}=22,740 ; \\
p=.000\end{array}$} \\
\hline $\begin{array}{l}\text { Destekleyici ve } \\
\text { Ilımlı Örgüt İklimi }\end{array}$ &,- 428 &, 069 &,- 413 & $-6,220$ & \\
\hline Makyavelizm &, 179 & ,059 &, 201 & 3,021 & \\
\hline 3 (Sabit) & 3,536 & ,284 & & 9,272 & \multirow{4}{*}{$\begin{array}{l}\mathrm{R}=, 535 ; \mathrm{R}^{2}=, 286 ; \mathrm{F}_{(3,181)}=24,168 \\
\mathrm{p}=.000\end{array}$} \\
\hline $\begin{array}{l}\text { Destekleyici ve } \\
\text { Ilımlı Örgüt İklimi }\end{array}$ &,- 456 &, 066 &,- 440 & $-6,961$ & \\
\hline Makyavelizm &, 085 &, 060 &, 096 & 1,432 & \\
\hline Etkileşim Terimi &, 254 & 054 &, 313 & 4,671 & \\
\hline
\end{tabular}

Yapılan hiyerarşik regresyon analizinin birinci modelinde bağımsız değişken olan destekleyici ve 1lımlı örgüt iklimi algısı ile bağımlı değişken olan iş yeri nezaketsizliği; ikinci modelde ise destekleyici ve 1lımlı örgüt iklimi algısı ile düzenleyici değişken olan makyavelizm; son modelde ise regresyon analizine destekleyici ve 1lımlı örgüt iklimi algısı, makyavelizm ile birlikte etkileşim terimi dahil edilmiştir. Tablo 4'e göre hiyerarşik regresyon modelinin bütün aşamaları istatistiksel olarak anlamlı bulunmuştur. Etkileşim teriminin bulunmadığı birinci gruptaki destekleyici ve 1lımlı örgüt iklimi alg1s1 $\left(\mathrm{F}_{(1,183)}=34,809 ; \mathrm{p}=.000\right)$ ve ikinci gruptaki destekleyici ve 1 lımlı örgüt iklimi alg1sı ile makyavelizmin $\left(\mathrm{F}_{(2,182)}\right.$ $=22,740 ; \mathrm{p}=.000)$ regresyon modeline anlamlı katk1 yaptığını göstermektedir. 
Örgüt İkliminin İsyeri Nezaketsizliği Üzerine Etkisinde Makyavelist Kişilik Özelliklerinin Düzenleyici Rolü

Düzeltilmiş $\mathrm{R}^{2}$ değerleri sırasıyla 0.16 ve $0.20^{\prime}$ dir. $\mathrm{Bu}$ sonuç iş yeri nezaketsizliğideki değişimin \%16'lık kısmını destekleyici ve 1lımlı örgüt iklimi algısı, \%20'lik kısmını ise destekleyici ve 1lımlı örgüt iklimi algısı ile makyavelizmin birlikte açıkladığını göstermektedir. Tablo 4 'te modeller bazında katsayılar incelendiğinde, birinci grupta modele dâhil edilen destekleyici ve $11 \mathrm{lml}$ örgüt iklimi algıs1 alg1s1 $(B=-, 414, p<0.01)$; ikinci grupta modele dâhil edilen destekleyici ve 1 lımlı örgüt iklimi algısı $(B=-, 428, p<0.01)$ ile makyavelizm $(\mathrm{B}=, 179, \mathrm{p}<0.01)$; üçüncü grupta ise modele dâhil edilen destekleyici ve 1lımlı örgüt iklimi algısı $(B=-456, p<0.01)$ ile makyavelizm $(B=, 085, p<0.01)$ ve etkileşimsel terim $(B=, 254, p<0.01)$ iş yeri nezaketsizliği üzerinde anlamlı etkiye sahiptir.

Son olarak destekleyici ve 1lımlı örgüt iklimi alg1sı ile makyavelizmin etkileşiminin biçimini ve yönünü belirlemek için, düşük ve yüksek düzeydeki (ortalama değerinden +1 ve -1 standart sapmadaki makyavelizm olduğu durumlarda) destekleyici ve 1 lımlı örgüt iklimi algısının iş yeri nezaketsizliği üzerindeki etkisi grafiksel olarak Şekil 2'de gösterilmiştir.

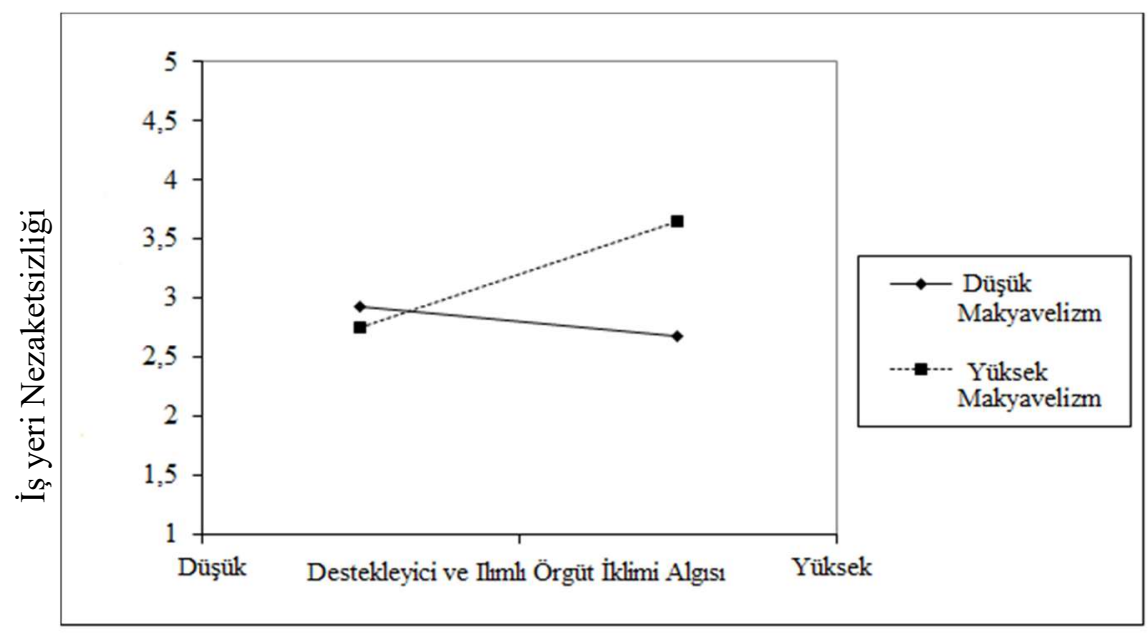

Şekil 2. Destekleyici ve Ilımlı Örgüt İkliminin İş Yeri Nezaketsizliği ile İlişkisinde Makyavelizmin Düzenleyici Rolü

Bireylerin düşük ya da yüksek makyavelist kişilik özelliklerine sahip olup olmaması ile düşük ve yüksek iş yeri nezaketsizliği ile destekleyici ve 1lımlı örgüt iklimi ile ilişkisini gösteren Şekil 2' deki eğimlerin, 0 (sıfır) değerinden anlamlı düzeyde farklılaşıp farklılaşmadığ eğim testi (slope test) ile analiz edilmiştir (Aiken ve West, 1991). Bu test örgütlerin destekleyici ve 1lımlı örgüt iklimi algıS1 ile iş yeri nezaketsizliği arasındaki ilişkinin bireylerin makyavelist kişilik özelliklerine bağlı olup olmadığını ortaya koymaktadır. Şekil 2 iş yeri nezaketsizliği üzerinde destekleyici ve 1lımlı örgüt iklimi algısı ve makyavelist 
kişilik özelliklerinin (etkileşimsel) etkisinin var olduğunu göstermektedir. Düşük makyavelist kişilik özelliği için yüksek destekleyici ve 1lımlı örgüt iklimi algısı iş yeri nezaketsizliğini düşürmektedir. Yüksek makyavelist kişilik özelliği için ise destekleyici ve 1 lımlı örgüt iklimi artıkça iş yeri nezaketsizliği de artmaktadır. $\mathrm{Bu}$ sonuçlara göre, iş yeri nezaketsizliği ile destekleyici ve 1lımlı örgüt iklimi algısı arasındaki ilişki makyavelist kişilik özellikleri tarafından biçimlenmektedir.

\section{Sonuç}

Örgüt ikliminin iş yeri nezaketsizliği üzerine etkisinde makyavelist kişilik özelliğinin düzenleyici rolünün tespit edilmesi adına yapılan araştırmada kavramsal çerçeve ve alan yazın göz önünde bulundurularak oluşturulan model test edilmiştir. Belirtilen örneklem çerçevesinde elde edilen verilerin analizi ile gerçekleştirilen çalışmada açıklayıcı ve doğrulayıcı faktör analizi ile ölçeklere ilişkin veri yapıları test edilmiştir. Sonrasında ise değişkenler arasındaki ilişkilerin ortaya konulmasına yönelik korelasyon analizi, değişkenler arasındaki doğrudan ve dolaylı etkiler ile düzenleyici etkilere yönelik bulgular için ise hiyerarşik regresyon analizi yapılmıştır.

Çalışmanın kurgusu doğrultusunda gerçekleştirilen analiz sonuçları incelendiğinde destekleyici ve 1 lımlı örgüt iklimi algısı ile iş yeri nezaketsizliği ve makyavelist kişilik özellikleri arasındaki ilişkilerin istatistiki olarak anlamlı $(\mathrm{p}<0.01 ; \mathrm{p}<0.05)$ olduğu görülmüştür. Bu anlamda destekleyici ve 1 lımlı örgüt iklimi algısı artıkça iş yeri nezaketsizliğinin ve makyavelist kişilik özelliklerinin azalacağ $1(\mathrm{r}=-.40$ ve $\mathrm{p}=0.01 ; \mathrm{r}=-.07$ ve $\mathrm{p}=0.05)$ söylenebilir. Banka sektörü çalışanlarının destekleyici ve 1 lımlı örgüt iklimi algısı algılarının yükseltilmesi, örgütlerde istenmeyen davranışlar arasında yer alan iş yeri nezaketsizliği ve makyavelist kişilik özelliklerinde azalmaya yardımcı olacaktır. Yine analiz sonuçlarına göre banka çalışanlarının destekleyici ve ılımlı örgüt iklimine ilişkin algılarının oldukça yüksek olduğu söylenebilir $($ ort=3,49). Çalışanların makyavelist kişilik özelliklerinin ortalamanın üzerinde seyrettiği buna karşın iş yeri nezaketsizliğinin ortalamanın altında olduğu görülmüştür. $\mathrm{Bu}$ anlamda bankacilık sektörü destekleyici ve 1lımlı örgüt algısının yüksek olduğu, çalışanların ortalamanın üzerinde makyavelist kişilik özelliklerine sahip olduğu buna karşın iş yeri nezaketsizliğinin ortalamanın altında seyrettiği bir yapıya sahiptir.

Yapılan analizler sonucunda destekleyici ve 1lımlı örgüt iklimi algısının iş yeri nezaketsizliği üzerinde negatif yönlü ve anlamlı bir etkiye sahip olduğu görülmektedir. Bu anlamda 1lımlı, destekleyici ve olumlu bir örgüt psikolojisinin yaratıldığ1 örgütlerde iş yeri nezaketsizliğinin azalacağ Araştırmanın bu sonucu alan yazın ile de paralellik göstermektedir. Taştan (2014) yapmış olduğu çalışmasında örgüt iklimi ve iş yeri nezaketsizliği arasında orta düzeyde pozitif ve anlamlı ilişkiler tespit etmiştir. $\mathrm{Bu}$ anlamda örgütü tanımlayan ve örgütün tümüne yayılan olumlu havanın çalışanların moral ve 
Örgüt İkliminin İsyeri Nezaketsizliği Üzerine Etkisinde Makyavelist Kişsilik Özelliklerinin Düzenleyici Rolü

motivasyonlarını etkiyerek iş yerinde istenmeyen davranışlara engel olacağı düşünülmektedir. Yaratılacak olumlu örgüt iklimi ile çalışanların sorun ve çatışmalardan uzaklaşarak birlik ve beraberlik içinde çalışacakları örgütsel bir yapı oluşacaktır. Bu anlamda iş yeri nezaketsizliği gibi üretkenlik ve verimlilik karşıtı davranışlar yaratılacak olumlu ve 1lımlı bir örgüt iklimi ile en aza indirilecektir. Bu anlamda araştırmanın birinci hipotezi olan " $\mathbf{H}_{1}$ : Destekleyici örgüt iklimi iş yeri nezaketsizliğini negatif yönlü ve anlamlı olarak etkilemektedir. " kabul edilmiştir.

Araştırmanın ikinci hipotezini test etmek amacıyla yapılan analizde destekleyici ve 1 lımlı örgüt iklimi algısının iş yeri nezaketsizliği üzerindeki etkisinde makyavelist kişilik özellikleri düzenleyici olarak modele dahil edilmiştir. Analiz sonucunda makyavelist kişilik özelliklerinin modelde düzenleyici bir rol üstlendiği görülmüştür. Yani, destekleyici ve 1lımlı örgüt iklimi algısı ile iş yeri nezaketsizliği arasındaki ilişkinin makyavelist kişilik özellikleri tarafından biçimlendiği söylenebilir. Buna göre düşük makyavelist kişilik özelliğine sahip bireyler için destekleyici ve 1 lımlı örgüt iklimi algısı yükseldikçe iş yeri nezaketsizliği azalmaktadır. Ancak yüksek makyavelist kişilik özelliğine sahip bireyler için destekleyici ve 1lımlı örgüt ikliminin varlığına ilişkin alg1 iş yeri nezaketsizliği de artmaktadır. Yüksek makyavelist kişilik özelliklerine sahip bireyler örgüt içinde var olan destek ve 1lımlı örgüt iklimine nezaketsiz davranışlarla cevap verebilirken; düşük makyavelist kişilik özelliklerine sahip bireylerin artan destek ve 1lıml örgüt iklimi ile sergileyecekleri nezaket dışı davranışlar azalacaktır. Bu anlamda araştırmanın "H2: Makyavelist kişilik özelliği destekleyici örgüt iklimi ile iş yeri nezaketsizliği arasında düzenleyici bir rol üstlenmektedir.” hipotezi kabul edilmiştir.

$\mathrm{Bu}$ çalışma destekleyici ve 1 lımlı örgüt iklimi algısı ve iş yeri nezaketsizliği arasındaki ilişkide makyavelist kişiliğin nasıl bir rol üstlendiğine odaklanmaktadır. Yukarıda da değinildiği gibi iş yeri nezaketsizliği ile örgüt iklimi arasındaki ilişkileri belirlemeye yönelik çeşitli çalışmalar bulunmaktadır. Bunlardan Taştan (2014) olumsuz örgüt iklimi algısı ile iş yeri nezaketsizliği arasında orta düzeyde pozitif ve anlamlı ilişkiler tespit etmiştir. Yine alan yazında iş yeri nezaketsizliği ile kişilik özellikleri arasında ilişki olduğunu belirten çalışmalar bulunmasına karşın (Bartlett vd., 2008; Gökçe 2008; Lewis ve Malecha, 2011; Scheuer, 2010; Shim, 2010; Terlecki, 2011) doğrudan makyavelist kişilik özelliklerini ve bu özelliklerin düzenleyici etkisini konu alan bir çalışmaya rastlanmamıştır. Bu yüzden araştırmanın bu sonucunu alan yazın ile karşılaştırma imkanı bulunamamıştır.

Çalışanların, örgüt liderleri ve çalışma arkadaşları tarafından işlerini yapması sırasında ne kadar yardım ve destek aldığına ilişkin algısı (Hughes vd., 2008) yükseldikçe o örgütte amaç ve hedeflere ulaşma konusunda daha fazla iş birlikçi yaklaşımlar benimsenecektir. Çalışanlarda iyi ve olumlu duygular uyandıran bir ortamı ifade eden destekleyici örgüt iklimi açık ilişkiler ve dostluk temelinde şekillenmektedir. Örgüt üyelerinin birbirini desteklediği ve 
cesaretlendirdiği bu örgüt iklimi ile örgüt içinde daha az nezaket dışı davranışın görüleceği araştırmanın beklenen sonucunu oluşturmaktadır. Yine beklenen bir sonuç olarak düşük makyavelist kişilik özellikleri gösteren bireylerin destekleyici ve 1 lımlı bir örgüt iklimi ile daha az nezaket dışı davranışa yöneleceğidir. Ancak beklenenden farklı olarak yüksek düzeyde makyavelist kişilik özelliklerine sahip bireylerin destekleyici ve 1lımlı örgüt iklimi algıları ile daha yıkıcı ve nezaketsiz davranışlarda bulunmasıdır. Makyavelist kişilik özelliklerini yoğun şekilde benimsemiş çalışanların örgüt içinde hissedecekleri destek algısı onları daha vurdum duymaz ve korkusuz hale getirebilmektedir. Amaçları doğrultusunda diğer bireyleri manüpile eden, ikiyüzlü, samimiyetsiz çalışanların desteklendiklerine ilişkin sahip olacakları algı onları daha kırıcı, saygısız ve soğukkanlı hale getirebilmektedir. Bunun bir sonucu olarakta müşterilere, çalışma arkadaşlarına ve hatta yöneticilerine karşı yıkıcı nezaketsiz davranışlar sergilemekten çekinmeyeceklerdir.

Bilindiği gibi destekleyici ve 11 ımlı bir örgüt iklimi sayesinde çalışanların kendi iş arkadaşlarına ve örgüte karşı geliştirdikleri negatif tutum ve davranışlar değişebilmektedir. Destekleyici ve 1 lımlı örgüt iklimi sayesinde çalışanları olumsuz iş davranışları ve çıktılarına yönelten iş yeri nezaketsizliğinin de önüne geçilmiş olacaktır. Ancak bu araştırma bunun her zaman böyle olmadığını göstermektedir. Destekleyici ve 1 lımlı örgüt ikliminin iş yeri nezaketsizliği için bir çözüm olabilmesi için bireylerin düşük düzeyde makyavelist kişilik özelliğine sahip olması gerekmektedir. Aksi takdirde yüksek makyavelist kişilik özellikleri ile destekleyici ve ılımlı bir örgüt iklimi yıkıcı ve negatif tutum ve davranışlardan oluşan iş yeri nezaketsizliğini artırmaktadır.

Düşük makyavelist kişilik özellikleri taşıyan bireyler, örgütsel uygulama ve politikalar ile desteklendiğine ilişkin olumlu algıya sahip olan çalışanlar enerjilerini çalışma arkadaşları ve yöneticilerini manipüle etme, kendi güçsüz yönlerini saklama, yalan ve hileye başvurma gibi olumsuz eylemlere harcamaktansa kişisel iyi olma, örgütsel başarı ve verimlilik gibi kavramlara yönlendirebilecektir. Yine bu çalışanlar kendi çıkar ve başarısı uğruna sosyal çevresini ve ilişkilerini tehlikeye atmaktansa birlik ve beraberlik ruhu içinde örgütsel amaç ve hedeflere ulaşmak adına kendi iş gereklerine odaklanabilecektir. Azalan makyavelist kişilik özellikleri ile örgüt içinde ortaya çıkacak olan işbirlikçi ve güvene dayalı ilişkiler çalışanların daha mutlu ve huzurlu olmasına katkı sağlayacaktır. Bireyde başlayan bu olumlu duygulanım kısa bir sürede örgütün tümüne yayılacaktır. Bu sayede örgüt içinde oluşacak sevgi, saygı ve güven temelli ilişkiler nezaket dışı davranışlar önünde bir engel teşkil edecektir.

Bilindiği gibi davranış teoristyenlerinden Skinner'ın (1938) tanımladığ edimsel koşullanma, organizmanın eylem ve davranışlarının sonuçlarına göre o davranışın sıklığının artmasına veya azalmasına dayanır. Bu kuramın temel kavramları "edimsel koşullanma ve pekiştirme"dir. Kuramda da belirtildiği gibi desteklenen davranışın tekrar edilme olasılığı artmaktadır. Yüksek makyavelist kişilik özelliklerinin sergilendiği bir örgüt içinde hâkim olan örgüt ikliminin 
Örgüt İkliminin İsyeri Nezaketsizliği Üzerine Etkisinde Makyavelist Kişsilik Özelliklerinin Düzenleyici Rolü

destekleyici ve 1lımlı olarak devam arz etmesi bu makyavelist çalışanların iş yeri nezaketsizliği içeren davranışlarını ödüllendirme görevi üstlenmektedir. $\mathrm{Bu}$ anlamda makyavelist kişilik özelliklerinin yoğun şekilde görüldüğü örgütlerde yaratılacak destek algisı ve bu kişiler tarafından yapılan yanlışların cezalandırılmayışı makyavelist kişilik özelliklerini daha yoğun ve baskın bir şekilde sergileme ortamını yaratacaktır.

Başarı ve gücün insan kaynağının bilgi, yetenek ve performansına bağlı olduğu bankacılık gibi insan ilişkilerinin önem arz ettiği sektörlerde nezaketsiz davranışların sonuçları beklenenden daha da yıkıcı olmaktadır. Gelişme ve değişimlere açık, işbirliği ve takım çalışmasına yatkın düşük makyavelist kişilik özelliklerine sahip nitelikli çalışanların amaçlar doğrultusunda oluşturacakları sinerji örgütlerin rekabet yeteneklerini de belirlemektedir. Bu anlamda iyi ilişkileri temel alan, güven ve yardımlaşmanın bulunduğu örgütler destekleyici ve 1 lımlı bir örgüt iklimi oluşturarak bu kişilerin zaten az olan makyavelist kişilik özelliklerine duyacakları ihtiyacı en aza indirecektir. Bu anlamda sosyal bir varlık olan insanın bir gruba ait olma, sevme-sevilme gibi ihtiyaçları da göz önünde bulundurulduğunda örgüt içinde nezaket üzerine kurulu bir yapı oluşacaktır.

Örgütlerin stratejik amaç ve hedeflerine ulaşmasında büyük önem arz eden çalışanların sahip olacağı destekleyici ve 1 lımlı örgüt algısının iş yeri nezaketsizliği ile ilişkileri ve bu ilişkide makyavelist kişilik özelliğinin nasıl bir rol üstlendiği bu araştırma ile ortaya konulmaya çalışılmıştır. $\mathrm{Bu}$ anlamda kavramların birlikte ve derinlemesine irdelenmesi ile elde edilen sonuçların örgütlere ve uygulayıcılara yardımcı olacak bilgiler içerdiğine inanılmaktadır. Destekleyici ve 11 mlı bir örgüt ikliminin önemini ve gücünü kavrayan yönetici ve liderler çalışanlarını iş yeri nezaketsizliğinden uzaklaştıracak uygulama ve politikalardan daha etkin bir şekilde yararlanacaktır. Yine bu noktada bu ilişkiye yön veren kavramın düşük ve yüksek makyavelist kişilik özelliklerinin olduğu unutulmamalıdır. Özellikle hizmet sektörü için örgütlerin insan kaynakları departmanlarının personel seçme ve sağlama yol ve yöntemlerinde kişilik testlerini etkin şekilde kullanarak makyavelist kişilik özelliklerini tespit etmeleri önemlidir. Mevcut çalışanlar için ise makyavelist kişilik özelliklerini azaltabilecek eğitim ve geliştirme faaliyetleri planlanmalıdır. Bu çalışanların çeşitli eğitimler ve terapiler yardımı ile bir nebzede olsa örgüt için yıkıcı davranışlardan uzaklaşacağı düşünülmektedir.

Her araştırmada olduğu gibi bu araştırmanın da belli kısıtları bulunmaktadır. Örgüt içindeki psikolojik havayı ifade eden örgüt iklimi, makyavelizm ve iş yeri nezaketsizliği kavramları bireylerin algıları doğrultusunda varlık göstermektedir. Bu anlamda kavramları somutlaştırmak adına anket yönteminin kullanılması ve sorulara verilen cevapların subjektif olması en önemli kısıtı oluşturmaktadır. Yine araştırma sonuçlarının örneklem ile sınırlı olması genellemelerin yapılmasını güçleştirmektedir. Bundan sonraki çalışmalar için farklı örneklem grupları ile çalışmanın tekarlanarak sonuçların karşılaştırılması önerilmektedir. İnsan ilişkilerinin yoğun yaşandığı hizmet 
sektöründe örgüt iklimi, kişilik ve ortaya çıkan davranışların belirlenmesine yönelik yapılacak olan çalışmalar ile verilen hizmetin kalitesinin artırılacağına inanılmaktadır. $\mathrm{Bu}$ anlamda kavramların farklı değişkenler ile ilişkilerini belirlemeye yönelik yapılacak çalışmalar ile alan yazına katkı sağlanacağı düşünülmektedir. Yine yönetici ve çalışanlardan destekleyici ve 1lımlı bir örgüt ikliminin yaratımı konusunda neler beklendiği açıkça paylaşılarak bu psikolojik havanın işbirliği içinde oluşturulacağına ilişkin yaratılacak algı büyük önem arz etmektedir.

\section{Kaynaklar}

Aiken, LS., West, SG. (1991), Multiple Regression: Testing and Interpreting Interactions, Newbury Park: Sage.

Alay, H. (2016), A Study on The Relationship Between Organizational Climate and Mobbing Behaviors at The Workplace, Yüksek Lisans Tezi, Marmara Üniversitesi Sosyal Bilimler Enstitüsü, İstanbul.

Andersson, LM., Pearson CM. (1999), Tit For Tat? The Spiraling Effect of Incivility in The Workplace. Academy of Management Review 24(3), 452471.

Arslan, M. (2001), Yönetim ve Organizasyonun Bazı Temel Kavramları, S. GÜNEY, Yönetim ve Organizasyon, (s. 25-44) Ankara: Nobel Yayın Dağıtım.

Ayan, A. (2017), Makyavelist Kişilik Eğilimi Algılarının Yaşamın Anlamı ve Yaşam Doyumu Üzerine Etkisi. Yönetim ve Ekonomi, 24(1). 52-72.

Ayan, A., Ünsar, S., Kahraman, G. (2013), A Research on The Determination of Machiavellian Personality Tendencies, Eskişehir Osmangazi Üniversitesi Sosyal Bilimler Dergisi, 14(1), 103-121.

Aydoğan, E., Serbest, S. (2016), İş Yerinde Karanlık Üçlü: Bir Kamu Kuruluşunun İç Denetim Biriminde Araştırma, Sayıştay Dergisi, (101), 97-121.

Aydoğan, ZF. (2004), Makyavelizm ve İklimi. Gazi Üniversitesi Ticaret ve Turizm Eğitim Fakültesi Dergisi, (2), 203-215.

Baron, RA., Neuman, JH. (1996), Workplace Violence and Workplace Aggression: Evidence On Their Relative Frequency and Potential Causes. Aggressive Behavior, 22(3), 161-173.

Bartlett, JE., Bartlett, ME., Reio, JR. (2008), Workplace Incivility: Worker and Organizational Antecedents and Outcomes, Amerika Birleşik Devletleri İnsan Kaynakları Geliştirme Akademisi Uluslararası Araştırma Konferans1, Online sunum, 20-24 Şubat, Panama.

Blau, G., Andersson, L. (2005), Testing a Measure of Instigated Workplace Incivility, Journal of Occupational \& Organizational Psychology, 78(4), 595-611. 
Örgüt İkliminin İsyeri Nezaketsizliği Üzerine Etkisinde Makyavelist Kişsilik Özelliklerinin Düzenleyici Rolü

Browne, MW., Cudeck, R. (1993), Alternative Ways of Assessing Model Fit, KA. BOLLEN, JS. LONG, Testing Structure Equation Models, (s. 136162), Newbury Park: Sage Publications.

Bulutlar, F., Öz, EÜ. (2009), The Effects of Ethical Climates on Bullying Behaviour in The Workplace, Journal of Business Ethics, 86(3), 273-295.

Büte, M. (2011), Etik İklim, Örgütsel Güven ve Bireysel Performans Arasındaki İlişki. Atatürk Üniversitesi İktisadi ve İdari Bilimler Dergisi, 25(1), 171192.

Byrne, BM. (2001), Structural Equation Modeling with AMOS, EQS, and LISREL: Comparative Approaches to Testing for The Factorial Validity of A Measuring Instrument. International Journal of Testing, 1(1), 55-86.

Carter, SL. (1998), Civility: Manners, Morals, and The Etiquette of Democracy. New York: Basic Books.

Castro, M., Martins, N. (2010), The Relationship Between Organisational Climate and Employee Satisfaction in A South African İnformation and Technology Organisation, SA Journal of Industrial Psychology, 36(1), 800-809.

Chatman, A. J. (1989). Improving Interactional Organizational Research: A Model of Person-Organization Fit, Academy of Management Review, 14(3): 333-349.

Christie, R., Geis, $\quad$ F. (1970), Scale Construction, Studies In Machiavellianism, 34(4), 10-34.

Cindiloğlu Demirer, M. (2019). Kişi Örgüt Uyumunun İş Performansı Üzerine Etkisi: Mutluluğun Aracilık Rolü. Ataturk University Journal of Economics \& Administrative Sciences, 33(1).

Cingöz, A., Kaplan, A. (2015), The Effect of Workplace Incivility on Job Satisfaction and Organizational Trust: A Study of Industrial Enterprises in Turkey, The 2015 WEI International

Academic Conference Proceeding, Vienna, Austria, 12-15.

Cortina, LM., Magley, VJ. (2009), Patterns and Profiles of Response To Incivility in The Workplace. Journal of Occupational Health Psychology, 14(3), 272-288.

Cortina, LM., Magley, VJ., Williams, JH., Langhout, RD. (2001), Incivility In The Workplace: Incidence and Impact. Journal Of Occupational Health Psychology, 6(1), 64-80.

Çangarlı, BG. (2009), A Review of Organizational Antecedents of Bullying. International Journal of Business Research, 9(6), 100-106.

Çekmecelioğlu, HG. (2006), Örgüt İklimi, Duygusal Bağll1ık ve Yaratıc1lık Arasındaki İlişkilerin Değerlendirilmesi: Bir Araştırma, Atatürk Üniversitesi Íktisadi ve İdari Bilimler Dergisi, 20(2), 295-310.

Çekmecelioğlu, H. (2005), Örgüt İkliminin İş Tatmini ve İşten Ayrılma Niyeti Üzerindeki Etkisi: Bir Araştırma, C.Ü. İktisadi ve İdari Bilimler Dergisi, 6(2), 23-39. 
Çırpan, H. (1999), Örgütsel Öğrenme İklimi ve Örgüte Bağlllık Illişkisi: Bir Alan Araştırması. Yayınlanmamış Doktora Tezi, İstanbul Üniversitesi Sosyal Bilimler Enstitüsü, İstanbul.

Çokluk, Ö., Şekercioğlu, G., Büyüköztürk, Ş. (2012), Sosyal Bilimler İçin Çok Değişkenli İstatistik SPSS ve LISREL Uygulamaları, (2. Baskı). Ankara: Pegem Akademi Yayıncılık.

Dahling, JJ., Whitaker, BG., Levy, PE. (2009), The Development and Validation of A New Machiavellianism Scale. Journal of Management, 35(2), 219257.

Delen, MG. (2011), Çalışma Hayatında İş Yeri Kabalığı Olgusu, Maliye Araştırma Merkezi Konferansları, İstanbul Üniversitesi, 2-3 Kasım, Isparta, 43-58.

Demirtaş, Ö., Biçkes, DM. (2014), Makyavelizm'in Olumsuz Durumları İfşa Etme Niyeti Üzerindeki Etkisi: Bir Alan Çalışması, İşgüç The Journal of Industrial Relations and Human Resources, 16(2), 96-112.

Dion, MJ. (2006), The Impact of Workplace Incivility and Occupational Stress on The Job Satisfaction and Turnover Intention of Acute Care Nurses, ABD: University of Connecticut.

Dönertaş, C. (2008), Etik İklimin Kuruma Güven Üzerindeki Etkisi, Marmara Üniversitesi Sosyal Bilimler Enstitüsü, Yayınlanmamış Yüksek Lisans Tezi, İstanbul.

Eren, E., Çekmecelioğlu, H. (2002), Örgüt Yaratıc1lığı ve Verimliliğinin Sağlanmasında Örgüt İkliminin Rolü, 10.Ulusal Yönetim Ve Organizasyon Kongresi, Akdeniz Üniversitesi, 23-25 Mayıs, Antalya, 585592.

Ertuğrul, O., Özçelik, O. (2018), İnsan Kaynakları Uygulamalarının Tükenmişlik Sendromu Üzerindeki Etkisinde Örgüt Ikkliminin Düzenleyici Rolüne Yönelik Bir Araştırma, Doktora Tezi, İstanbul Üniversitesi Sosyal Bilimler Enstitüsü, İstanbul.

Genç, N., Karcioğlu, F. (2000), Örgüt İkliminin Gücü Aşkale Çimento Örneği, İstanbul: Karizma Yayınları.

Gladwell, M. (1996), The Tipping Point, The New Yorker, 72(14), 32-36.

Gökçe, AT. (2008), Mobbing: İş Yerinde Yıldırma Nedenleri ve Başa Çıkma Yöntemleri. Ankara: Öğreti: PEGEM Akademi.

Guterman, SS. (1970), The Machiavellians: A Social Psychological Study Of Moral Character and Organizational Milieu, Lincoln: University of Nebraska Press.

Gültaç, AS. (2019), Örgütsel Sapma ve Nezaketsizlik Davranışları İlişkisinde İs yerinde Dişlanmanın Aracı Rolü: Sağllk Kurumlarında Bir Araştırma, Yüksek Lisans Tezi Hacettepe Üniversitesi Sosyal Bilimler Enstitüsü, Ankara. 
Örgüt İkliminin İsyeri Nezaketsizliği Üzerine Etkisinde Makyavelist Kişsilik Özelliklerinin Düzenleyici Rolü

Güney, S., Mandacı, G. (2009), Makyavelizm ve Etik Algısı İlişkileri: Bankacılık Sektöründe Bir Araştırma, Hacettepe Üniversitesi İktisadi ve İdari Bilimler Fakültesi Dergisi, 27(2), 83-104.

Halis, M., Uğurlu, ÖY. (2008), Güncel Çalışmalar Işs̆ğında Örgüt İklimi. İşgüç The Journal of Industrial Relations and Human Resources, 10(2), 101123.

Haller, BV. (1971), Industrial and Organizational Psychology, (3.bask1), New York: McGraw Hill.

Halpin, AW. (1966), Theory and Research In Administration, England: Macmillan.

Campbell, RJ., Hinsie, LE. (1970), Psychiatric Dictionary, England: Oxford U. Press.

Hossny, EK., Qayed, MH., Yoyssef, HR. (2015), Effect of Workplace Civility, Structural and Psychological Empowerment on Newly Graduated Nurses Organizational Commitment at Hospitals in Assiut City, IOSR Journal of Nursing and Health Science, 4(6), 87-95.

Hughes, JN., Luo, W., Kwok, OM, Loyd, LK. (2008), Teacher-Student Support, Effortful Engagement, and Achievement: A 3-Year Longitudinal Study, Journal of educational psychology, 100(1), 1-14.

Işıkay, Ç. (2018), İş yeri Nezaketsizliği, Tükenmişlik ve İs Doyumu İlişkisinde Örgütsel Adalet Algısının Aracılık Rolü: Muğla İli Kamu Hastaneleri Birliğinde Görev Yapan Hemşireler Üzerine Bir Araştırma, Doktora Tezi, Muğla Sitkı Kocaman Üniversitesi Sosyal Bilimler Enstitüsü, Muğla.

İşcan, ÖF., Karabey, CN. (2007), Örgüt İklimi İle Yeniliğe Destek Algısı Arasındaki İlişki. Gaziantep Üniversitesi Sosyal Bilimler Dergisi, 6(2), 180-193.

Jacobson, VL. (2007), Workplace Aggression: Employee Attitudes, Perceptions, and Behaviors In Aggressive Work Climates, Yayınlanmamış Doktora Tezi, Department of Psychology, Capella University, A.B.D.

James, LR., James, LA. (1989), Integrating Work Environment Perceptions: Explorations İnto The Measurement of Meaning, Journal of Applied Psychology, 74(5), 739-751.

Johnson, CL. (1988), Socially Controlled Civility, American Behavioral Scientist, 31(6), 685-701.

Johnson, PR., Indvik, J. (2001), Slings and Arrows of Rudeness: Incivility in The Workplace. Journal of Management Development, 20(8), 705-714.

Kanten, P. (2014), İş yeri Nezaketsizliğinin Sosyal Kaytarma Davranışı Ve İşten Ayrılma Niyeti Üzerindeki Etkisinde Duygusal Tükenmenin Aracılık Rolü. Aksaray Üniversitesi İktisadi ve İdari Bilimler Fakültesi Dergisi, 6(1), 11-26.

Karc1oğlu, F. (2001), Örgüt Kültürü Ve Örgüt İklimi İlişkisi, Atatürk Üniversitesi Íktisadi ve İdari Bilimler Dergisi, 15(1-2), 265-283. 
Kaya, N., Koç, E., Topçu, D. (2010), An Exploratory Analysis of The Influence of Human Resource Management Activities and Organizational Climate on Job Satisfaction in Turkish Banks. The International Journal of Human Resource Management, 21(11), 2031-2051.

Kirk, B., Schutte, N., Hine, D. (2009), Chapter 9 The Role of Emotional Selfefficacy, Emotional Intelligence, and Affect in Workplace Incivility and Workplace Satisfaction, In Emotions in Groups, Organizations and Culture (s. 211-225) Bingley: Emerald Group Publishing Limited.

Kline, RB. (2005), Methodology In The Social Sciences, New York: Guilford Press.

Kozlowski, SWJ., Doherty, ML. (1989), Integration of Climate and Leadership: Examination of A Neglected Issue. Journal of Applied Psychology. 74(4), 546- 553.

Köse, S., İspirli, D., Eryılmaz, İ. (2014), Düzenleyici Odaklar ve İş Yeri Nezaketsizliği İlişkisinde Örgütsel İklimin Düzenleyici Etkisi: Keşfedici Bir Araştırma, 2.Örgütsel Davranış Kongresi Bildiriler Kitabı. Melikşah Üniversitesi, 7-8 Kasım, Kayseri, 243.

Kumral, T. (2017), İs yeri nezaketsizliği ve Örgütsel Sessizlik İlişkisinde Örgütsel Dışlanmanın Aracı Rolü, Yüksek Lisans Tezi, Marmara Üniversitesi Sosyal Bilimler Enstitüsü, İstanbul.

Kutanis, R., Özsoy, E., Karakiraz, A., Uslu, O. (2015), Örgütsel Davranış Araştırmalarında Kişiliğin Karanlık Yönü (Narsisizm, Makyavelizm ve Psikopati) Dikkate Alınıyor mu?, 23. Ulusal Yönetim ve Organizasyon Kongresi, 14-16 Mayıs, Muğla.

Laschinger, SHK., Leiter, M., Day, A., Gilin, D. (2009), Workplace Empowerment, Incivility and Burnout: Impact on Staff Nurse Recruitment and Retention Outcomes, Journal of Nursing Management, 17(3), 302311.

Leiter, MP., Day, A., Oore, DG., Laschinger, HK. (2012), Getting Better and Staying Better: Assessing Civility, Incivility, Distress, and Job Attitudes One Year After A Civility Intervention. Journal of occupational health psychology, 17(4), 425-434.

Lewis, PS., Malecha, A. (2011), The Impact of Workplace Incivility on The Work Enviroment, Manager Skill and Productivity, The Journal of Nursing Administration, 41(1), 41-47.

Leymann, H., Gustafsson, A. (1996), Mobbing At Work and The Development Of Post-Traumatic Stress Disorders, European Journal Of Work and Organizational Psychology, 5(2), 251-275.

Lim, S., Cortina, LM., Magley, VJ. (2008), Personal and Workgroup Incivility: Impact on Work and Health Outcomes, Journal of Applied Psychology, 93(1), 95-107.

Litwin, HG., Stringer, R. (1968), Motivation and Organizational Climate, Boston: Division of Harward Business School. 
Örgüt İkliminin İsyeri Nezaketsizliği Üzerine Etkisinde Makyavelist Kişsilik Özelliklerinin Düzenleyici Rolü

Machiavelli, N. (2003), Prens (çev. I. Gündüz) İstanbul: Morpa Kültür Yayınları. Marsh, HW., Balla, JR., Mcdonald, RP. (1988a), Goodness-of-fit Indexes in Confirmatory Factor Analysis: The Effect of Sample Size. Psychological Bulletin, 103(3), 391-410.

Marsh, HW., Hocevar, D. (1988b), A New, More Powerful Approach to Multitrait-Multimethod Analyses: Application of Second-Order Confirmatory Factor Analysis, Journal of Applied Psychology, 73(1), 107117.

Martin, J. (1996), Miss Manners Rescues Civilization. New York: Crown Publishers.

Meier, LL., Semmer, NK. (2012), Lack of Reciprocity, Narcissism, Anger, and Instigated Workplace Incivility: A Moderated Mediation Model, European Journal of Work and Organizational Psychology, 26(1), 1-15.

Menemencioğlu, GBK. (2018), Çalışanların Kendi Değerlerine ve Yöneticilerin Değerlerine Iliş̧kin Algılarının İşe Yabancılaşma Duygularına Etkisi: Örgüt İkliminin Aracı Rolü, Doktora Tezi, İstanbul Ticaret Üniversitesi, Sosyal Bilimler Enstitüsü, İstanbul.

Miner, KN., Settles, IH., Pratt-Hyatt, JS., Brady, CC. (2012), Experiencing Incivility in Organizations: The Buffering Effects of Emotional and Organizational Support, Journal of Applied Social Psychology, 42(2), 340-372.

Mullins, LJ. (1993), Management and Organizational Behavior, (6.bask1), England: Prentice Hall.

Nelson, DL., Quick, JC. (1997), Organizational Behaviour, Foundations Realities and Challenges, St.Poul M.N.: West Publishing Company.

Özer, Ö., Uğurluoğlu, Ö., Kahraman, G., Avcı, K. (2016), Hemşirelerin Karanlık Kişilik Özelliklerinin Sosyodemografik Değişkenler Açısından İncelenmesi. Manisa Celal Bayar Üniversites,i Sosyal Bilimler Dergisi, 14(3), 205-217.

Özkul, Y. (2013), Örgüt Ikkliminin Motivasyon Üzerine Etkisi: Bir Uygulama, Yüksek Lisans Tez Çalışması, Marmara Üniversitesi, Sosyal Bilimler Enstitüsü, Çalışma Ekonomisi ve Endüstri İlişkileri Anabilim Dalı Yönetim ve Çalışma Psikolojisi Bilim Dalı, İstanbul.

Özsoy, E., Ardıç, K. (2017), Karanlık Üçlü'nün (Narsisizm, Makyavelizm ve Psikopati) İş Tatminine Etkisinin İncelenmesi, Yönetim ve Ekonomi Dergisi, 24(2), 391-406.

Patterson, MG., West, MA., Shackleton, VJ., Dawson, JF., Lawthom, R., Maitlis, S., Wallace, AM. (2005), Validating the Organizational Climate Measure: Links to Managerial Practices, Productivity and Innovation. Journal of Organizational Behavior, 26(4), 379-408.

Paulhus, DL., Jones, DN. (2009), Chapter 7 Machiavellianism, MR Leary ve RH Hoyle, Individual Differences in Social Behavior, (s. 93-108), New York: Guilford. 
Paulhus, DL., Williams, KM. (2002), The Dark Triad of Personality: Narcissism, Machiavellianism, and Psychopathy. Journal of Research in Personality, 36(6), 556-63.

Pearson, CM., Porath, CL. (2005), On the Nature, Consequences, and Remedies of Workplace Incivility: No Time For "Nice"? Think Again. The Academy of Management Executive, 19(1), 7-18.

Penney, LM., Spector, PE. (2005), Job Stress, Incivility, and Counterproductive Work Behavior (Cwb): The Moderating Role of Negative Affectivity, Journal of Organizational Behavior, 26(7), 777-796.

Polatc1, S., Özçalık, F. (2013), Yapısal ve Psikolojik Güçlendirmenin İş Yeri Nezaketsizliği ve Tükenmişliğe Etkisi. İşletme Bilimi Dergisi, 1(1), 17-34.

Pritchard RD., Karasick, BW. (1973), The Effects of Organizational Climate Managerial Job Performance and Job Satisfaction, Organization \& Human Performance, 9(1), 126ᄀ146.

Robbins, SP. (1998), Organizational Behavior: Concepts, Controversies, Applications, New Jersey: Prentice Hall Inc.

Roberts, MC. (1985), A Plea For Professional Civility. Professional Psychology: Research and Practice. 16(4), 474-474.

Sabur, E. (2011), Makyavelist Kişilik Özelliklerinin Muhasebe Denetimindeki Yeri ve Denetçi Davranışlarına Etkileri, Abant İzzet Baysal Üniversitesi, Yüksek Lisans Tezi, Bolu.

Schein, E. (1992), Organizational Culture and Leadership, San Francisco: Jossey Bass.

Scheuer, ML. (2010), A Climate for Workplace Aggression: The Influence of Abusive Supervision, Organizational Factors, and Subordinate Predispositions, Yayınlanmamış Doktora Tezi, Northern Illinois University, Department of Psychology, A.B.D.

Shadur, MA., Kienzle, R., Rodwell, J. (1999), The Relationship Between Organizational Climate and Employee Perceptions of Involvement: The Importance of Support, Group \& Organization Management, 24(4), 425479.

Shalley, CE., Gilson, LL., Blum, TC. (2000), Matching Creativity Requirements and The Work Environment: Effects on Satisfaction and Intentions to Leave, Academy of Management Journal, 43(2), 215-223.

Shim, JH. (2010), The Relationship Between Workplace Incivility and The Intention to Share Knowledge: The Moderating Effects of Collaborative Climate and Personality Trait,. Yayınlanmamass Doktora Tezi, Psychology Faculty of University of Minnesota, ABD.

SIMMONS, DC. (2008), Organizational Culture, Workplace Incivility, and Turnover: The Impact of Human Resources Practices, Yayınlanmamış Doktora Tezi, University of Louisville, Department of Education Leadership Foundations, ABD. 
Örgüt İkliminin İsyeri Nezaketsizliği Üzerine Etkisinde Makyavelist Kişsilik Özelliklerinin Düzenleyici Rolü

Skinner, B. (1938), The Behavior of Organisms: An experimental analysis.; Available at: http://opensiuc.lib.siu.edu/tpr/vol47/iss4/5/ adresinden alınd.

Soljan, I., Josipovic-Jelic, Z., Titlic, M. (2009), Organizational Circumstances For The Occurrence Of Mobbing In Health Care Organizations, Macedonian Journal of Medical Sciences, 2(3), 1-6.

Stringer, R. (2002), Leadership and Organizational Climate, Upper Saddle River, NJ: Prentice-Hall.

Sümer, N. (2000), Yapisal Eşitlik Modelleri: Temel Kavramlar ve Örnek Uygulamalar. Türk Psikoloji Yazıları, 3(6), 49-74.

Şimşek, Z. (2007), CEO Tenure and Organizational Performance: An Intervening Model. Strategic Management Journal, 28(6), 653-662.

Tabachnick, BG., Fidell, LS., Ullman, JB. (2007), Using Multivariate Statistics (5.bask1). Boston: Pearson.

Tarraf, RC. (2012), Taking A Closer Look at Workplace Incivility: Dimensionality and Source Effects, Yüksek Lisans Elektronik Tezi ve Tez Deposu, The University Western Ontario, Department of Psychology, Kanada.

Taştan, SB. (2014), İş yeri Nezaketsizliğini Öngören Örgütsel ve Durumsal Önceller ile Çalışanların Davranışsal Sonuçları Arasındaki İlişkinin ve Sosyo - Psikolojik Kaynakların Rolünün İncelenmesi: Sağlı Kurumlarında Yapılan Bir Araştırma, Işs, Gü̧̈ Endüstri Illişkileri ve İnsan Kaynaklari Dergisi, 16(3), 60-75.

Terlecki, SA. (2011), Exploring Individual and Organizational Level Antecedents of Experienced Workplace Incivility, Yayınlanmamış Yüksek Lisans Tezi, Department of Psychology, Faculty of the University of Tennessee, Chattanooga, ABD.

Uçkun, CG., Üzüm, B., Uçkun, S. (2018), Narsist Kişiliğin Makyavelist Davranışlara Etkisi: Kocaeli Üniversitesi Özel Güvenlik Öğrencileri Örneği, Afyon Kocatepe Üniversitesi Sosyal Bilimler Dergisi, 20(2), 139154.

Yüceler, A. (2009), Örgütsel Bağl1lık ve Örgüt İklimi İlişkisi: Teorik ve Uygulamalı Bir Çalışma, Selçuk Üniversitesi Sosyal Bilimler Enstitüsü Dergisi, (22), 445-458.

Yücetürk, EE., Öke, MK. (2005), Mobbing and Bullying: Legal Aspects Related to Workplace Bullying in Turkey. South East Review, (2), 61-70.

Zapf, D., Knorz, C., Kulla, M. (1996), On The Relationship Between Mobbing Factors and Job Content Social Work Environments and Health Outcomes, European Journal of Work and Organizational Psychology, 5(2), 215-237. 